\title{
Trade and Jobs in U.S. Manufacturing
}

\author{
Jeffrey D. Sachs; Howard J. Shatz; Alan Deardorff; Robert E. Hall
}

Brookings Papers on Economic Activity, Vol. 1994, No. 1. (1994), pp. 1-84.

Stable URL:

http://links.jstor.org/sici?sici=0007-2303\%281994\%291994\%3A1\%3C1\%3ATAJIUM\%3E2.0.CO\%3B2-7

Brookings Papers on Economic Activity is currently published by The Brookings Institution.

Your use of the JSTOR archive indicates your acceptance of JSTOR's Terms and Conditions of Use, available at

http://www.jstor.org/about/terms.html. JSTOR's Terms and Conditions of Use provides, in part, that unless you have obtained prior permission, you may not download an entire issue of a journal or multiple copies of articles, and you may use content in the JSTOR archive only for your personal, non-commercial use.

Please contact the publisher regarding any further use of this work. Publisher contact information may be obtained at http://www.jstor.org/journals/brookings.html.

Each copy of any part of a JSTOR transmission must contain the same copyright notice that appears on the screen or printed page of such transmission.

JSTOR is an independent not-for-profit organization dedicated to and preserving a digital archive of scholarly journals. For more information regarding JSTOR, please contact support@jstor.org. 
JEFFREY D. SACHS

Harvard University

HOWARD J. SHATZ

Harvard University

\section{Trade and Jobs in U.S. Manufacturing}

DURING THE PAST 15 years, the U.S. economy has become increasingly integrated with the rest of the world. Among other trends, imports and exports have risen significantly as a percentage of U.S. gross domestic product. Many manufacturing sectors have shrunk in the face of stiff international competition; others have grown in response to strong international demands for U.S. exports. One of the notable features of this internationalization is the growing importance of trade with the developing countries. In 1978, developing countries accounted for 29.0 percent of U.S. manufactured goods imports. By 1990, that ratio had risen to 36.4 percent. Seven countries in East Asia (China, Hong Kong, Korea, Malaysia, Singapore, Taiwan, and Thailand), together with Brazil and Mexico, accounted for 79 percent of the increase in U.S. trade with all developing countries between 1978 and 1990.

Many observers have linked the growing internationalization of the U.S. economy to important trends in the U.S. labor market. Three labor

We would like to thank Alan Deardorff, Robert Hall, Robert Lawrence, Matthew Slaughter, and Adrian Wood for extensive discussions and suggestions on earlier drafts of this paper. We would also like to thank several people for their generous and extensive assistance regarding the collection and interpretation of the underlying data: Nick Orsini and Blake Sanders, Trade Data Services Branch, Foreign Trade Division, U.S. Bureau of the Census; Ed Coan, Industry and Commodity Classifications Branch, Economic Census and Surveys Division, U.S. Bureau of the Census; John Collins, Documents Division, Harvard University Libraries; David Howell, New School for Social Research; and Joseph Flynn, Office of Economics, U.S. International Trade Commission. We especially thank Flynn for necessary last-minute efforts. We also thank Jennifer Harris and Allen Woo for research assistance. 
market trends of the past 15 years are of particular concern: (1) the sharp decline of overall employment in manufacturing; (2) the widening of the income inequality between high-skilled and low-skilled workers; and (3) the especially sharp decline in employment in low-skill manufacturing sectors. ${ }^{1}$ In other words, one sees a situation of job losses in manufacturing, with low-skilled workers taking the brunt of the adjustment. It is widely presumed that trade with developing countries is putting special pressure on low-skill manufacturing sectors in the United States, such as textiles, apparel, and footwear.

The precise role of international trade in these trends remains unclear. In the view of some leading trade economists, the effects of internationalization have been minimal. As Paul Krugman and Robert Lawrence recently put it, "competition from abroad has played a minor role in the contraction of U.S. manufacturing." Similarly, Lawrence and Matthew Slaughter conclude that trade effects on wages and employment have been small. ${ }^{3}$ This view is also echoed by Jagdish Bhagwati and Vivek Dehejia and by the Clinton administration in the Economic Report of the President $1994 .{ }^{4}$ These observers point to technological change rather than internationalization as the major force behind the labor market trends.

Other economists, such as Edward Leamer and Adrian Wood, have recently reached the conclusion that increased internationalization is having a substantial effect on U.S. labor markets. ${ }^{5}$ As these authors stress, both the Heckscher-Ohlin-Samuelson (HOS) model and standard models of international capital mobility predict that internationalization will narrow the gap between U.S. and rest-of-the-world wages and widen the gap between wages of skilled and unskilled workers within the United States. Moreover, these standard theories predict that U.S. manufacturing sectors that are intensive in low-skilled workers will

1. Lawrence and Slaughter convincingly account for a fourth phenomenon, the slow overall growth of real wages, as attributable to slow overall productivity growth in the economy, rather than to international trade per se. Our own focus is not on the overall growth of real wages, but on wage inequalities and the patterns of employment in manufacturing.

2. Paul R. Krugman and Robert Z. Lawrence, "Trade, Jobs, and Wages," Scientific American, April 1994, pp. 44-49.

3. Lawrence and Slaughter (1993, p. 165).

4. Bhagwati and Dehejia (1993).

5. Leamer $(1993,1994)$ and Wood (1994). 
shrink in the face of increased integration with developing countries abundant in low-skilled workers. Earlier studies by labor economists have also reached the conclusion that changing trade patterns have been contributing to shifts in the labor market-in particular, to the loss of low-skill employment in manufacturing. ${ }^{6}$

This paper takes yet another look at the role of trade in recent labor market developments, in part by assembling a new data base that allows us to trace the patterns of U.S. foreign trade according to a detailed breakdown of trade by manufacturing industry and partner country. For most of the analysis, we rely on a disaggregation of trade into 131 manufacturing categories (three-digit SIC classification) and more than 150 trading partners, including developed and developing countries. Our main focus is on the period 1978-90, during which time U.S. trade with developing countries expanded significantly. Strangely enough, it is difficult to get data on trade by industry and country on a consistent basis before 1978 (see appendix A for details).

We find that internationalization has indeed contributed to the trend noted earlier: the decline of manufacturing employment, particularly of low-skilled workers. According to our main estimates, the increase in net imports between 1978 and 1990 is associated with a decline of 7.2 percent in production jobs in manufacturing and a decline of 2.1 percent in nonproduction jobs in manufacturing. Since production jobs, overall, are less highly skilled than nonproduction jobs, these trends may have contributed to the widening of wage inequalities between skilled and unskilled workers. This would be the case if increased trade not only shifted labor out of low-skill jobs but also reduced the relative prices of products made predominantly with low-skilled labor (such as apparel, footwear, and textiles imported by the United States from low-wage countries). In that case, according to the Stolper-Samuelson proposition of standard international trade theory, the wages of low-skilled labor

6. See, for example, Murphy and Welch (1991), who find that shifts in trade during the 1980s agreed with observed changes in industrial employment patterns, and Borjas, Freeman, and Katz (1991), who find a role for trade in both increasing the effective supplies of low-skilled workers and widening the wage differential between low-skilled and high-skilled workers. Their findings are consistent with those of Revenga (1992) and MacPherson and Stewart (1990), as well as Borjas and Ramey (1993), who find that imports of durable goods have a major effect on wage inequality. Note, however, that a number of studies have not found trade effects-for example, Davis and Haltiwanger (1991). Levy and Murnane (1992) have an excellent review of the literature on wage inequality. 
would be pushed down relative to the wages of high-skilled labor. Relative product prices seem to have moved in the indicated direction, but not dramatically so, as we describe later.

We agree with Krugman and Lawrence and with Lawrence and Slaughter that increased internationalization cannot, by itself, account for most of the observed labor market trends. The overall changes in employment and in wage inequalities are too large to be explained by the changing trade and price patterns of the past 15 years. It is likely that technological change is playing a role independent of internationalization. Yet, we cannot precisely measure the relative importance of these two factors-trade and technology-mainly because one cannot observe and measure technological change with any precision. We do not believe in choosing one or the other explanation, however: both are at work, a point also stressed recently by Leamer. ${ }^{7}$

The plan of the paper is as follows. In the next section, we review the basic macroeconomic data on the decline of manufacturing sector employment and the shift in wage patterns and introduce the data on the internationalization of the U.S. economy. We find a prima facie case that internationalization is playing an important role in the labor market. In the subsequent section, we calculate the effects of trade on manufacturing employment, separating the effects of trade with developed and developing countries. The data suggest a net decline in employment of low-skilled workers as the result of changes in trade flows between 1978 and 1990. Circumstantial evidence also points to a role for trade competition in increased wage inequality, but the macroeconomic data are not sufficient to render a clear verdict. We also examine some evidence on the role of transnational corporations (TNCs) in U.S. trade with developing countries. It appears that TNCs are a conduit for increased internationalization of the U.S. economy and that U.S. trade is especially high with countries in which a high proportion of trade passes through U.S. transnational firms.

In the final section, we make some rough estimates of future trade flows with some of the key low-wage regions: China, India, the former socialist economies, and Mexico. We believe that the scope of international trade with these low-wage regions is likely to grow significantly, adding to the adjustment burden of low-skilled workers. We also specu-

7. Leamer (1994). 
Table 1. Production, Employment, and Trade in Manufactured Goods, 1950-90

Percent

\begin{tabular}{|c|c|c|c|c|c|c|}
\hline Year & $\begin{array}{c}\text { Manufactur- } \\
\text { ing GDP } \\
\text { to total } \\
G D P\end{array}$ & $\begin{array}{l}\text { Manufactur- } \\
\text { ing } \\
\text { employment } \\
\text { to total } \\
\text { employment }\end{array}$ & $\begin{array}{c}\text { Manufactur- } \\
\text { ing imports } \\
\text { to total } \\
G D P^{\mathrm{a}}\end{array}$ & $\begin{array}{l}\text { Manufac- } \\
\text { turing } \\
\text { imports to } \\
\text { manufac- } \\
\text { turing } \\
\text { GDP }\end{array}$ & $\begin{array}{l}\text { Manufac- } \\
\text { turing net } \\
\text { imports to } \\
\text { total GDP }\end{array}$ & $\begin{array}{c}\text { Manufactur- } \\
\text { ing net } \\
\text { imports to } \\
\text { manufactur- } \\
\text { ing GDP }\end{array}$ \\
\hline 1950 & 29.3 & 33.7 & $\ldots$ & $\ldots$ & $\ldots$ & $\ldots$ \\
\hline 1960 & 28.2 & 31.0 & 2.1 & 6.5 & -1.0 & -3.2 \\
\hline 1970 & 25.0 & 27.3 & 3.5 & 11.8 & -0.1 & -0.3 \\
\hline 1978 & 23.3 & 23.7 & 5.4 & 18.3 & 0.6 & 1.9 \\
\hline 1990 & 18.5 & 17.4 & 7.3 & 30.7 & 1.5 & 6.5 \\
\hline
\end{tabular}

Sources: Authors' calculations using Economic Report of the President 1994, tables B-11, B-44; NBER productivity data set; and NBER trade, employment, and immigration data files, with extensions as described in appendix A (industry data).

a. Imports are U.S. manufacturing imports from partner countries.

b. Net imports are U.S. manufacturing imports from partner countries minus U.S. manufacturing exports to partner countries.

late briefly about increases in the trade of services and the likely implications for U.S. labor market developments.

\section{International Trade and U.S. Manufacturing}

In broad terms, the concerns over trade competition come from the confluence of several trends, shown in table 1 . The share of the manufacturing sector as a percent of GDP is falling; the share of manufacturing employment as a percent of total nonagricultural employment is falling; the share of manufacturing imports as a percent of manufacturing GDP is rising; and the share of net manufacturing imports (equal to imports minus exports) as a percent of manufacturing GDP is also rising. The key questions are whether these trends are causally linked, and how.

Krugman and Lawrence argue that the linkage is mostly spurious and that, to the extent that a real linkage exists, it is very small. They point out that the fall in the manufacturing share of GDP has been a secular trend since well before the rapid internationalization of the economy that started in the 1970s. They argue that the decline is due mainly to a secular decline in the relative price of manufactures compared with nonmanufactures, which in turn is due to the relatively rapid growth of productivity in manufacturing. If one assumes an aggregate price elasticity of demand of less than one, the secular fall in the relative price of manu- 
factures translates into a declining share of consumption of manufactured goods, and thereby (assuming balanced international trade) into a declining share of manufacturing production in GDP.

They explain the decline in the employment share the same way. Just as in agriculture, where high productivity growth led to the dwindling of agricultural employment, so too in manufacturing it is the "success" in productivity increases that is driving jobs out of the sector. As they put it,

Ironically, the conventional wisdom here has things almost exactly backwards. Policymakers often ascribe the declining share of industrial employment to a lack of manufacturing competitiveness brought on by inadequate productivity growth. In fact, the shrinkage is largely the result of high productivity growth, at least as compared with the service sector. The concern, widely voiced during the 1950s and 1960s, that industrial workers would lose their jobs because of automation is closer to the truth than the current preoccupation with a presumed loss of manufacturing jobs because of foreign competition. ${ }^{8}$

This argument is correct about the general direction of long-term trends, but it glosses over the particularly sharp decline in manufacturing employment as a percentage of total employment during the 1970s and 1980s. It fails to note that the proportional decline in manufacturing employment was much faster after 1978 than before. From 1950 to 1978, manufacturing employment actually increased by 5.3 million workers, or by 1.1 percent a year, albeit less than the 2.4 percent a year increase in total nonagricultural employment. Between 1978 and 1990, by contrast, manufacturing employment actually fell by 1.4 million workers, or by 0.6 percent a year, while total nonagricultural employment rose by 2.0 percent a year, just slightly below the previous rate. ${ }^{9}$

If the 1978-90 growth of manufacturing employment had mimicked the 1950-78 record, in the sense of growing by 1.3 percentage points a year less than economywide employment, there would have been 0.7 percent annual growth $(=2.0-1.3)$ in manufacturing employment, or an increase of 1.7 million jobs, rather than the actual fall of 1.4 million jobs. Thus, there is an "unexplained" gap of 3.1 million workers. The manufacturing employment puzzle is heightened further by the 1990-93 period. While overall employment rose by 752,000 between 1990 and 1993,

8. Krugman and Lawrence, Scientific American, April 1994, pp. 46-47.

9. Economic Report of the President 1994, table B-44. 
manufacturing employment fell by 1.3 million. Long-term trends are surely not enough to account for the manufacturing job losses after 1978.

Of course, much more work is needed to decide whether trade flows can plausibly account for much of the drop in manufacturing employment. As Krugman and Lawrence as well as Lawrence and Slaughter point out, another reason for the particularly large fall in manufacturing employment could be the slow growth of nonmanufacturing productivity in the 1980s. Manufacturing sector employment tends to shrink when manufacturing productivity grows faster than service sector productivity. This can be the result of rapid growth of manufacturing productivity, or a slowdown in the growth of service sector productivity. The latter seems to have played a role in the 1980s, perhaps in addition to shifts resulting from international trade.

According to estimates presented later, shifts in international trade accounted for a net decline of 5.9 percent of 1978 employment levels, or 1.2 million jobs, out of the 3.1 million "jobs puzzle." Thus, by this estimate, international trade accounts for part of the loss of manufacturing jobs-about 39 percent-but not for the whole story. Still, it is a substantial proportion, worthy of close scrutiny.

The employment puzzle is complemented by a wage puzzle. During the past 15 years, the gap between the wages of skilled and unskilled workers has risen sharply. This trend toward widening inequality has been documented in a wide range of data, both at the household and industry levels. We follow work by Eli Berman, John Bound, and Zvi Griliches in using the category "nonproduction workers" from the Annual Survey of Manufactures to proxy for skilled workers in manufacturing. ${ }^{10}$ Unskilled workers in turn, are proxied by "production workers." We then use the gap between average earnings of production and nonproduction workers to proxy for the gap between skilled and unskilled workers. Many other researchers, including Lawrence and Slaughter, have also followed this route. In appendix B, we elaborate on the use of the nonproduction-production distinction to proxy for the skilled-unskilled distinction.

The ratio of the wages of skilled to unskilled workers, measured in this fashion, is shown in table 2 . We find that the rise in this ratio is a phenomenon of the 1980s. The ratio dipped in the early $1960 \mathrm{~s}$, rose and

10. Berman, Bound, and Griliches (1994). 
Table 2. Average Annual Wages in the United States, 1961-90

Dollars, except as noted

\begin{tabular}{|c|c|c|c|}
\hline Year & $\begin{array}{l}\text { Production } \\
\text { employees }^{\mathrm{a}}\end{array}$ & $\begin{array}{l}\text { Non- } \\
\text { production } \\
\text { employees }^{\mathrm{b}}\end{array}$ & $\begin{array}{l}\text { Ratio of } \\
\text { nonpro- } \\
\text { duction } \\
\text { wage to } \\
\text { produc- } \\
\text { tion wage }\end{array}$ \\
\hline 1961 & 4,662 & 7,383 & 1.58 \\
\hline 1962 & 4,887 & 7,635 & 1.56 \\
\hline 1963 & 5,063 & 7,794 & 1.54 \\
\hline 1964 & 5,307 & 8,074 & 1.52 \\
\hline 1965 & 5,456 & 8,463 & 1.55 \\
\hline 1966 & 5,653 & 8,900 & 1.57 \\
\hline 1967 & 5,818 & 9,268 & 1.59 \\
\hline 1968 & 6,215 & 9,714 & 1.56 \\
\hline 1969 & 6,491 & 10,259 & 1.58 \\
\hline 1970 & 6,748 & 10,572 & 1.57 \\
\hline $\begin{array}{l}1961-70 \\
\text { average }\end{array}$ & 5,630 & 8,806 & 1.56 \\
\hline 1971 & 7,217 & 11,204 & 1.55 \\
\hline 1972 & 7,799 & 12,177 & 1.56 \\
\hline 1973 & 8,313 & 12,925 & 1.56 \\
\hline 1974 & 8,946 & 13,821 & 1.54 \\
\hline 1975 & 9,661 & 15,096 & 1.56 \\
\hline 1976 & 10,540 & 16,295 & 1.55 \\
\hline 1977 & 11,482 & 17,593 & 1.53 \\
\hline 1978 & 12,398 & 18,999 & 1.53 \\
\hline 1979 & 13,266 & 20,250 & 1.53 \\
\hline 1980 & 14,255 & 21,863 & 1.53 \\
\hline $\begin{array}{l}1971-80 \\
\text { average }\end{array}$ & 10,388 & 16,022 & 1.54 \\
\hline 1981 & 15,670 & 24,013 & 1.53 \\
\hline 1982 & 16,515 & 25,192 & 1.53 \\
\hline 1983 & 17,407 & 26,954 & 1.55 \\
\hline 1984 & 18,439 & 28,958 & 1.57 \\
\hline 1985 & 19,369 & 30,152 & 1.56 \\
\hline 1986 & 20,110 & 31,170 & 1.55 \\
\hline 1987 & 20,414 & 32,609 & 1.60 \\
\hline 1988 & 21,165 & 34,137 & 1.61 \\
\hline 1989 & 21,695 & 35,811 & 1.65 \\
\hline 1990 & 22,389 & 36,824 & 1.64 \\
\hline $\begin{array}{r}1981-90 \\
\text { average }\end{array}$ & 19,317 & 30,582 & 1.58 \\
\hline
\end{tabular}

Source: Authors' calculations using NBER productivity data set with extensions as described in appendix A. a. Average annual production wage is aggregate production wages divided by production employees.

b. Average annual nonproduction wage is the difference of payroll minus production wages divided by the difference of total employment minus production employment. 
fluctuated without trend during the rest of the decade, and narrowed between 1970 and 1977. It was again fairly flat until 1982 and then started to rise appreciably. From the lowest point in 1982 to the maximum in 1990 , the ratio increased by 7.9 percent. Other researchers, using household survey data, have found that the wage gap between college-educated and high school-educated workers among young employed has risen by as much as 30 percent over the past 15 years. ${ }^{11}$ The widening of the wage gap attributable to education is generally dated to the late $1970 \mathrm{~s}$ and early 1980s, more or less in conformity with the timing in table 2 . Similar increases in wage inequality have been detected in other industrial economies, suggesting that global rather than U.S.-specific effects are at work. ${ }^{12}$ Of course, one candidate for a "global" effect is increased trade competition with developing countries.

The employment puzzle and the wage puzzle are distinct. It is possible that changes in international trade have caused large shifts in manufacturing employment without creating large effects on relative wages. According to HOS trade theory, and as emphasized by Lawrence and Slaughter and by Leamer, international trade will affect relative wages mainly through effects on relative output prices. Even large changes in the factor content of trade that accompany large changes in employment patterns will have little effect on relative wages unless output prices also change as a result of trade.

\section{Basic Patterns of Internationalization}

Table 1 shows that manufactured imports have grown markedly as a percent of aggregate GDP, especially after 1970. This trend is even clearer when comparing manufactured imports to manufacturing GDP (the value-added originating in manufacturing), shown in table 3 . Manufactured imports were just 6.5 percent of manufacturing value-added in 1960 ; by 1990 , they equaled 30.7 percent of manufacturing value-added.

11. See Freeman (1993) and his references.

12. See, for example, Machin (1994), who finds a pattern in the United Kingdom similar to that in the United States; Blau and Kahn (1994), who examine cross-country patterns; Katz, Loveman, and Blanchflower (1993), who find increasing inequality in the United Kingdom and Japan and very small increases in the late 1980s in France; Davis (1992), who finds increasing wage inequality in most advanced industrial economies during the 1980s. In contrast, Abraham and Houseman (1993) find virtually no evidence of increasing inequality in Germany. 
Table 3. Manufacturing Imports as a Share of Domestic Product and Manufacturing Value-Added by Country Group

Percent

\begin{tabular}{|c|c|c|c|c|c|c|}
\hline \multirow[b]{2}{*}{ Year } & \multicolumn{3}{|c|}{$\begin{array}{l}\text { U.S. manufacturing } \\
\text { imports to U.S. GDP }\end{array}$} & \multicolumn{3}{|c|}{$\begin{array}{l}\text { U.S. manufacturing imports } \\
\text { to U.S. manufacturing value-added }\end{array}$} \\
\hline & $\begin{array}{c}\text { All } \\
\text { countries }\end{array}$ & $\begin{array}{c}\text { Low- } \\
\text { wage } \\
\text { countries }^{\mathrm{a}}\end{array}$ & $\begin{array}{c}\text { Developing } \\
\text { countries }^{\mathrm{b}}\end{array}$ & $\begin{array}{c}\text { All } \\
\text { countries }\end{array}$ & $\begin{array}{c}\text { Low- } \\
\text { wage } \\
\text { countries }\end{array}$ & $\begin{array}{c}\text { Developing } \\
\text { countries }\end{array}$ \\
\hline 1960 & 2.1 & 1.8 & . . & 6.5 & 5.7 & $\cdots$ \\
\hline 1978 & 5.4 & 1.5 & 1.6 & 18.3 & 5.1 & 5.3 \\
\hline 1990 & 7.3 & 2.6 & 2.7 & 30.7 & 10.9 & 11.2 \\
\hline
\end{tabular}

Sources: Authors' calculations using NBER data sets with extensions; United Nations (1961); International Labour Office (various years); data from the U.S. Bureau of the Census as described in appendix A (trade data); and Data Resources, Inc.

a. Low-wage countries are all countries with a monthly wage less than or equal to 50 percent of the U.S. monthly wage.

b. Developing countries are the whole set of low-income countries identified in the text and appendix A.

Table 3 also shows the growing import penetration of low-wage countries after 1978. In the table, we show two classifications that are used throughout our study. In one classification, we separate U.S. trade partners into "low-wage" and "high-wage" categories. We consider a country a low-wage partner if its average manufacturing wage is 50 percent or less of the U.S. wage (data sources are described in appendix A). We also introduce the categories of "developing" and "developed" countries, using the World Bank's World Development Report of 1979, which is also described in appendix A. ${ }^{13}$

In 1960, almost all U.S. trade was with "low-wage" partners, since only Canada had average wages more than 50 percent of the U.S. average! By 1978, Japan and most of Western Europe had wages that were more than 50 percent of the U.S. level, so that these countries are reclassified as high-wage partners in 1978. Almost all of the remaining lowwage countries in 1978 are developing countries. This pattern of reclassification explains why U.S. trade with low-wage countries actually falls slightly (relative to GDP and to manufacturing value-added) between 1960 and 1978 and then rises steeply between 1978 and 1990. By 1990, manufactured imports from low-wage countries equaled 10.9 percent of U.S. manufacturing value-added, nearly twice the proportion of 1960 .

13. The anomalous classifications are Spain and Portugal as developing countries and Czechoslovakia and East Germany as developed economies. We maintain the World Bank classifications as is, so as to avoid mining the data. 
Krugman and Lawrence discount the importance of the rising trade with low-wage countries on the ostensible grounds that the new lowwage competition has merely replaced the former low-wage competition from Europe and Japan, which in turn has become "high-wage" competition. ${ }^{14}$ Table 3 indicates that Krugman and Lawrence overstate their case, since overall U.S. trade with low-wage countries has risen significantly as a percent of manufacturing value-added, and at least modestly relative to GDP as a whole. In fact, the timing of the fall and the rise of trade with low-wage partners is consistent with the timing of changes in wage inequality between low-skilled and high-skilled workers. It is plausible that the rise in wages in Europe and Japan between 1961 and 1978 reduced the competitive pressure on the wages of low-skilled workers in the United States, leading to a fall in wage inequality (with the ratio of the wages of nonproduction to production workers declining from 1.58 to 1.53$)$. Then, as trade with developing countries increased between 1978 and 1990, there was renewed downward pressure on lowskilled workers, thereby increasing the wage gap, with the wage ratio of nonproduction to production workers rising from 1.53 to 1.65 .

\section{Sources of Increased U.S. Trade with Developing Countries}

As a general matter, we view the increased U.S. trade as an exogenous force affecting the United States and other economies, rather than as a result of U.S. macroeconomic policies or other U.S.-centered causes. Increased U.S. trade reflects several deep-seated trends: international agreements on trade liberalization, especially the Tokyo Round of the General Agreement on Tariffs and Trade (GATT), completed in 1979, and the Uruguay Round, completed in 1993; market liberalization in the developing world; and the falling costs of communications and transport, which have boosted trade and the internationalization of pro-

14. According to Krugman and Lawrence, Scientific American, April 1994, p. 49:

Finally, increasing low-wage competition from trade with developing countries has been offset by the rise in wages and skill levels among traditional trading partners. Indeed, imports from low-wage countries were almost as large in 1960 as in 1990-2.2 percent of GDP-because three decades ago Japan and most of Europe fell in that category. In 1960 imports from Japan exerted competitive pressure on labor-intensive industries such as textiles. Today Japan is a high-wage country, and the burden of its competition falls mostly on skill-intensive sectors such as the semiconductor industry. 
Table 4. U.S. Imports by Country Group, 1978 and 1990

Millions of dollars and percent, as indicated

\begin{tabular}{|c|c|c|c|c|c|c|}
\hline \multirow[b]{2}{*}{ Country group } & \multicolumn{2}{|c|}{1978} & \multicolumn{2}{|c|}{1990} & \multicolumn{2}{|c|}{ Change, $1978-90$} \\
\hline & $\begin{array}{l}\text { Dollar } \\
\text { value }\end{array}$ & $\begin{array}{l}\text { Percent } \\
\text { share }^{\mathrm{a}}\end{array}$ & $\begin{array}{l}\text { Dollar } \\
\text { value }\end{array}$ & $\begin{array}{l}\text { Percent } \\
\text { share }^{\mathrm{a}}\end{array}$ & $\begin{array}{l}\text { Dollar } \\
\text { value }\end{array}$ & $\begin{array}{l}\text { Percent } \\
\text { share }^{\mathrm{a}}\end{array}$ \\
\hline All countries & 120,170 & 100.0 & 407,484 & 100.0 & 287,314 & 0.0 \\
\hline Developed countries & 85,255 & 70.9 & 259,308 & 63.6 & 174,053 & -7.3 \\
\hline Developing countries & 34,915 & 29.1 & 148,176 & 36.4 & 113,261 & 7.3 \\
\hline $\begin{array}{l}\text { Top nine developing } \\
\text { countries }^{b}\end{array}$ & 19,412 & 16.2 & 109,136 & 26.8 & 89,724 & 10.6 \\
\hline Taiwan & 5,061 & 4.2 & 22,122 & 5.4 & 17,060 & 1.2 \\
\hline Mexico & 3,067 & 2.6 & 20,617 & 5.1 & 17,549 & 2.5 \\
\hline Korea & 3,681 & 3.1 & 18,084 & 4.4 & 14,403 & 1.3 \\
\hline China & 230 & 0.2 & 13,730 & 3.4 & 13,500 & 3.2 \\
\hline Singapore & 1,013 & 0.8 & 9,257 & 2.3 & 8,244 & 1.5 \\
\hline Hong Kong & 3,265 & 2.7 & 9,011 & 2.2 & 5,746 & -0.5 \\
\hline Brazil & 1,689 & 1.4 & 6,958 & 1.7 & 5,269 & 0.3 \\
\hline Thailand & 354 & 0.3 & 4,692 & 1.2 & 4,339 & 0.9 \\
\hline Malaysia & 1,051 & 0.9 & 4,665 & 1.1 & 3,613 & 0.2 \\
\hline
\end{tabular}

Source: Authors' calculations using trade data from the U.S. Bureau of the Census (official statistics compiled by the U.S. Department of Commerce) as described in appendix A.

a. Shares are U.S. manufacturing imports from the country group (or country) divided by total U.S. manufacturing imports.

b. Countries are listed in decreasing order of their 1990 imports to the United States.

duction within transnational corporations. The rising role of developing countries in international trade also reflects the increased educational attainments in these countries (with average years of schooling rising from 2.4 in 1960 to 5.3 in 1986, according to Richard Freeman) and the rapid increases in the labor forces of the developing countries. ${ }^{15}$

Most of the increased U.S. trade with developing countries is with a small subset of partner countries. As is evident in table 4, from 1978 to 1990, nine countries account for four-fifths of the total increase in U.S. trade with developing nations: seven East Asian countries (China, Hong Kong, Korea, Malaysia, Singapore, Taiwan, and Thailand) and the two large Latin American economies (Brazil and Mexico). In essence, the 1980 s was the decade in which U.S. labor markets absorbed the "shock" of East Asian outward-looking industrialization and Latin American trade liberalization.

The East Asian economies built their export growth on the basis of low-wage labor, highly flexible labor markets, macroeconomic stability,

15. Freeman (1993). 
high educational attainment in relation to per capita income, very high national saving rates, and government support for manufactured exports. ${ }^{16}$ The export drives in the four East Asian tigers (Hong Kong, Korea, Singapore, and Taiwan) began in the 1960s and accelerated sharply in the 1970s. The export growth in Southeast Asia (especially Indonesia and Malaysia) started in the 1970s and then took off in the 1980s. Mainland China's trade reforms began in 1978 and produced remarkable export growth especially after the mid-1980s (growth was rapid from the very start of reforms, but it began from an extremely small base). ${ }^{17}$

The Latin American export growth came in the 1980s, especially in response to macroeconomic and trade policies that followed the onset of the debt crisis in the early 1980s. Brazil accelerated the internationalization of its economy, which had started in the mid-1960s. Brazil's longstanding and highly diversified manufacturing export sector grew markedly in the $1980 \mathrm{~s}$, in response to policy changes and real depreciation following the Brazilian debt crisis. Mexico's emergence as a diversified manufacturing exporter started in the mid-1980s, with a deep, acrossthe-board liberalization of the economy and the introduction of the $m a$ quiladora sector. Mexico's internationalization will be greatly intensified by the North American Free Trade Agreement (NAFTA).

The nine partner countries increased their trade sharply not only with the United States but also with the entire world. Their share of total trade (exports plus imports) as a proportion of total world trade (exports plus imports of all countries) rose from 7.4 percent in 1978 to 13.0 percent in 1990.

\section{International Trade Theory and U.S. Labor Market Trends}

Standard trade theory, in the form of the Heckscher-Ohlin-Samuelson (HOS) model, draws a possible link between increased U.S. trade with developing countries and observed trends in the U.S. labor market. ${ }^{18}$ In the basic two-good, two-factor model, each economy exports the good that is intensive in its abundant factor. If we suppose that the

16. See World Bank (1993) for a recent overview of the "East Asian miracle."

17. For a recent account of China's international trade performance in the reform era, see Lardy (1994).

18. See Deardorff (1994) for an overview of the Stolper-Samuelson theorem. 
two factors are skilled and unskilled labor, and that the United States is abundant in skilled labor and the developing countries are abundant in unskilled labor, we would expect the United States to export goods intensive in skilled labor and to import goods intensive in unskilled labor.

Note that the U.S. trade patterns will vary according to the partner country. U.S. trade with low-wage trading partners should follow the HOS pattern most strongly: U.S. exports of skill-intensive goods and imports of non-skill-intensive goods. U.S. trade with high-wage trading partners should be based much more on intra-industry trade in differentiated products than on differences in factor proportions.

Suppose that U.S. low-wage trading partners are partially closed to trade because of protectionist trade policies and that they then adopt liberalizing trade measures. HOS predicts the following set of outcomes in the United States: (1) the price of non-skill-intensive goods should fall relative to the price of skill-intensive goods, as the export supply of the former increases from the low-wage country; (2) the wage of unskilled workers should fall relative to the wage of skilled workers, in response to the fall in the relative price of the less skill-intensive goods; $;^{19}$ (3) production of skill-intensive goods should increase and the production of non-skill-intensive goods should decrease; (4) U.S. exports of skill-intensive goods and imports of non-skill-intensive goods should rise; and (5) each productive sector should increase the ratio of unskilled to skilled workers, in line with the fall in the relative wage of unskilled workers. In the partner country, the opposite trends should apply, with production shifting toward less skill-intensive goods, and the relative wage of unskilled workers tending to rise relative to the wage of skilled workers. ${ }^{20}$

In the simple HOS model, the overall employment of skilled and unskilled workers is assumed to remain unchanged in each country as

19. In fact, the Stolper-Samuelson theorem (Stolper and Samuelson, 1941), at the cornerstone of HOS trade theory, gives an even stronger result. Not only does the wage of unskilled workers fall relative to that of skilled workers; the wage of the unskilled falls in relation to both non-skill intensive and skill-intensive goods prices (and hence in real terms), while the wage of skilled workers rises in relation to both goods prices (and hence in real terms).

20. We do not look at the evidence in the developing countries, except to note briefly that the rise in the relative wage of unskilled workers has been observed in the case of Korea (Kim and Topel, 1994). 
these trade and product market changes take place. Note how the labor market equilibrium is preserved, assuming no change in total supply of skilled and unskilled labor. On the one hand, with the original factor proportions in each sector, there is increased demand for skilled workers in the United States since overall production shifts toward skill-intensive goods and away from the less skill-intensive ones (the opposite occurs in the low-wage partner country). On the other hand, there is a reduction in the demand for skilled workers within each subsector, as the lower relative wages of unskilled workers induce firms to raise the proportion of low-skilled workers in the production process (this is prediction 5 mentioned earlier). In the theoretical model, assuming full employment and no changes in the supplies of skilled and unskilled workers, these two forces exactly counterbalance each other to preserve labor market equilibrium.

We believe that low-wage competition did more than simply reallocate labor within manufacturing. We suspect that it actually resulted in net job losses in manufacturing. This can happen in the HOS framework if (1) the low-wage workers have a positive supply elasticity, so that a decline in their wage leads to a decline in labor force participation; (2) low-wage workers are unionized, and unions maintain wages above fullemployment levels; or (3) low-wage workers have alternative employment opportunities in nonmanufacturing (such as services), so that they leave the manufacturing sector entirely when international competition puts downward pressure on wages. We suspect that all of these responses have been important, though we are not able in this paper to provide a general equilibrium analysis of the effects of trade on employment throughout the whole economy.

\section{Adding Capital Mobility}

The HOS framework is not the only theoretical model of interest for linking trade flows with employment and wages. The HOS model assumes no capital mobility, only trade. Another part of the story of U.S. manufacturing employment and wages might be related to capital flows, and for that we need to amend the theoretical framework. Suppose, for purposes of illustration, there are two kinds of U.S. manufacturing firms: one uses high-skilled workers and physical capital, and the other uses low-skilled workers and physical capital. The developing country 
trade partner lacks skilled workers and initially lacks the physical capital needed to produce the non-skill-intensive good.

Because of the low wages in the developing country, there is an incentive to relocate physical capital there and then to produce for reexport to the United States. Such capital flows would depend on low transport and communications costs, an open trade regime in the developing country and the United States, and the developing country's openness to foreign direct investment, or other kinds of capital flows. Such conditions did not apply widely in the developing world until the 1980s, but can now be found much more widely than 10 years ago.

The result of the market opening would be a flow of capital from the United States to the developing country, a fall in the wage of unskilled workers in the United States relative to skilled workers, and a rise in non-skill-intensive imports from the developing country to the United States. The trade deficit would be paid for by a service account surplus: the earnings on the foreign investment would pay for the imports from the developing country. No change would be needed in the skill mix of production within each of the two sectors. (Indeed, in our example, one sector uses only skilled workers, and the other sector uses only unskilled workers.) Nor would any change be needed in the relative prices of the outputs of the two sectors. The level of unskilled employment might remain constant, with unskilled workers simply working for lower wages. Alternatively, unskilled workers might leave for other sectors of the economy, such as services.

This alternative model, which focuses on capital decumulation as a factor in reducing manufacturing employment and the wages of lowskilled workers, shows that foreign competition can affect employment and wages even without the HOS shifts in relative prices and skill intensity of production within manufacturing subsectors. We return to this theme later when we discuss the possible role of multinational corporations in the recent shifts in U.S. trade.

\section{Assessing the HOS Model for U.S. Trade}

How well does the HOS model explain U.S. trade patterns and recent trends in the labor market? To begin to answer this question, we classify the 131 three-digit manufacturing subsectors according to the skill intensity of production. We measure the intensity of low-skilled production 
Table 5. Characteristics of U.S. Manufacturing by Skill Decile, 1990

Percent

\begin{tabular}{|c|c|c|c|c|c|c|c|c|}
\hline \multirow[b]{2}{*}{$\begin{array}{c}\text { Skill } \\
\text { decile }\end{array}$} & \multirow{2}{*}{$\begin{array}{l}\text { Share of } \\
\text { production } \\
\text { employ- } \\
\text { ment in } \\
\text { total em- } \\
\text { ployment }\end{array}$} & \multirow[b]{2}{*}{$\begin{array}{c}\text { Share of } \\
\text { production } \\
\text { wages in } \\
\text { total } \\
\text { payroll }\end{array}$} & \multirow[b]{2}{*}{$\begin{array}{c}\text { Share of } \\
\text { capital in } \\
\text { value- } \\
\text { added, } \\
1978^{\mathrm{a}}\end{array}$} & \multicolumn{5}{|c|}{ Share of all manufacturing by skill decile } \\
\hline & & & & $\begin{array}{l}\text { Value- } \\
\text { added }\end{array}$ & $\begin{array}{l}\text { Produc- } \\
\text { tion em- } \\
\text { ployment }\end{array}$ & $\begin{array}{l}\text { Nonpro- } \\
\text { duction } \\
\text { em- } \\
\text { ployment }\end{array}$ & Imports & Exports \\
\hline 1 & 41.2 & 31.3 & 54.7 & 18.5 & 8.1 & 25.8 & 10.8 & 12.9 \\
\hline 2 & 56.6 & 46.9 & 56.0 & 14.4 & 8.8 & 14.9 & 10.1 & 24.3 \\
\hline 3 & 66.2 & 55.1 & 52.1 & 17.7 & 16.1 & 18.3 & 15.2 & 21.3 \\
\hline 4 & 71.3 & 61.9 & 48.4 & 7.4 & 8.8 & 7.9 & 9.5 & 7.0 \\
\hline 5 & 73.9 & 64.5 & 53.1 & 9.9 & 9.4 & 7.3 & 11.4 & 9.9 \\
\hline 6 & 76.6 & 68.1 & 44.0 & 7.6 & 9.9 & 6.7 & 6.1 & 4.1 \\
\hline 7 & 78.0 & 67.9 & 40.9 & 5.9 & 9.7 & 6.1 & 3.7 & 3.2 \\
\hline 8 & 81.2 & 75.7 & 44.7 & 11.1 & 12.7 & 6.6 & 20.9 & 12.7 \\
\hline 9 & 83.5 & 71.9 & 50.4 & 4.4 & 7.7 & 3.4 & 6.2 & 2.2 \\
\hline 10 & 86.7 & 77.8 & 44.5 & 3.4 & 8.7 & 3.0 & 6.0 & 2.5 \\
\hline
\end{tabular}

Source: Authors' calculations using the NBER productivity data set and U.S. Bureau of the Census (1981).

a. Share of capital in value-added is computed as one minus the ratio of total compensation to value-added and then converted to a percentage.

by the ratio of production workers to total workers in each manufacturing subsector in 1978. A higher ratio indicates a higher intensity of unskilled labor. We then aggregate the industries, according to this index, by deciles (that is, the 10 percent most skill-intensive industries, the next 10 percent most skill-intensive industries, and so on), with decile 1 signifying the most skill-intensive sectors and decile 10 signifying the least skill-intensive sectors.

The basic results of this aggregation are shown in table 5. In the table, we show the skill intensity of production, the share of capital in valueadded as well as the weight of each decile in total value-added, production and nonproduction employment, and the imports and exports of the manufacturing sector. In 1990, the most skill-intensive industries (decile 1) had a labor force in which production workers were 41.2 percent of employment. The least skill-intensive industries (decile 10), by contrast, had a labor force with production workers equal to 86.7 percent of employment. The share of production workers' payroll in the total payroll rises alongside the share of total production workers in employment.

In table 6, we also indicate some of the key industries in each decile. For example, the most skill-intensive decile includes periodicals and office and computing machines. The least skill-intensive decile includes footwear and many kinds of apparel. Motor vehicle production is in dec- 
Table 6. Key Industries within Each Skill Decile

\begin{tabular}{|c|c|c|}
\hline $\begin{array}{c}\text { Skill } \\
\text { decile }\end{array}$ & $\begin{array}{c}\text { Three- } \\
\text { digit } \\
\text { SIC } \\
\text { code }^{\mathrm{a}}\end{array}$ & Industry \\
\hline 1 & 272 & Periodicals \\
\hline 1 & 357 & Office and computing machines \\
\hline 2 & 372 & Aircraft and parts \\
\hline 2 & 281 & Industrial inorganic chemicals \\
\hline 3 & 351 & Engines and turbines \\
\hline 3 & 207 & Fats and oils \\
\hline 4 & 327 & Concrete, gypsum, and plaster \\
\hline 4 & 343 & Nonelectric plumbing and heating \\
\hline 5 & 387 & Watches, clocks, watch cases \\
\hline 5 & 394 & Toys and sporting goods \\
\hline 6 & 245 & Wood buildings and mobile homes \\
\hline 6 & 331 & Blast furnaces and basic steel \\
\hline 7 & 373 & Ship building and repair \\
\hline 7 & $251^{\mathrm{b}}$ & Furniture and fixtures \\
\hline 8 & 211 & Cigarettes \\
\hline 8 & 371 & Motor vehicles and equipment \\
\hline 8 & 332 & Iron and steel foundries \\
\hline 9 & 223 & Weaving, finishing mills, wool \\
\hline 9 & 311 & Leather tanning and finishing \\
\hline 10 & 236 & Girls' and children's outerwear \\
\hline 10 & 314 & Footwear, except rubber \\
\hline
\end{tabular}

Source: Authors' calculations using NBER productivity data set as described in appendix A.

a. From 1972 revision.

b. All of industry 25 was grouped together and labeled 251 .

ile 8 (relatively unskilled); basic steel is in decile 6; and many kinds of industrial machinery are in decile 3 .

In table 7, we show the 1990 pattern of U.S. trade by decile, for various groupings of partner countries. For each decile and country grouping, we measure the net trade balance relative to total trade flows. Letting $X_{i}$ be the dollar value of exports and $M_{i}$ be the dollar value of imports (for decile $i$ ), we measure $\left(X_{i}-M_{i}\right) /\left(X_{i}+M_{i}\right)$. We see clearly from the table that the basic HOS proposition holds for trade with developing country trade partners. With these partner countries, the United States tends to be a net exporter of skill-intensive products and a large net importer of non-skill-intensive products. This pattern is not evident for trade with the developed countries, for which differences in factor inten- 
Table 7. U.S. Net Trade as a Share of Total Trade by Country Group, Relative Wage Group, and Skill Decile, 1990

Percent

\begin{tabular}{|c|c|c|c|c|c|c|c|c|}
\hline \multirow[b]{3}{*}{$\begin{array}{c}\text { Skill } \\
\text { decile }\end{array}$} & \multirow{2}{*}{\multicolumn{3}{|c|}{ Net trade by country group }} & \multicolumn{5}{|c|}{ Net trade by relative wage group ${ }^{\mathrm{b}}$} \\
\hline & & & & & & & & 75 \\
\hline & $\begin{array}{c}\text { All } \\
\text { countries }\end{array}$ & $\begin{array}{l}\text { Devel- } \\
\text { oping } \\
\text { countries }\end{array}$ & $\begin{array}{c}\text { Devel- } \\
\text { oped } \\
\text { countries }\end{array}$ & $\begin{array}{c}0-10 \\
\text { percent }\end{array}$ & $\begin{array}{c}10-25 \\
\text { percent }\end{array}$ & $\begin{array}{c}25-50 \\
\text { percent }\end{array}$ & $\begin{array}{c}50-75 \\
\text { percent }\end{array}$ & $\begin{array}{l}\text { percent } \\
\text { and } \\
\text { over }\end{array}$ \\
\hline 1 & -3.0 & -16.4 & 3.2 & 0.1 & 1.1 & -8.5 & 1.4 & 1.1 \\
\hline 2 & 30.5 & 66.5 & 16.2 & 5.2 & 4.8 & 5.8 & 2.1 & 9.7 \\
\hline 3 & 4.8 & 10.9 & 0.1 & 2.3 & 2.6 & 1.4 & -0.1 & 0.4 \\
\hline 4 & -26.4 & -35.9 & -19.9 & -5.0 & -1.4 & -6.5 & -13.9 & -10.7 \\
\hline 5 & -19.1 & -21.1 & -17.9 & -3.2 & 0.4 & -2.7 & 1.1 & -16.3 \\
\hline 6 & -30.8 & -37.0 & -27.0 & -3.5 & -0.3 & -9.2 & -4.3 & -14.1 \\
\hline 7 & -18.1 & -34.7 & -5.8 & -5.4 & -3.0 & -10.7 & -5.5 & -2.5 \\
\hline 8 & -35.4 & -4.7 & -41.6 & -0.7 & -0.9 & 0.4 & -1.5 & -4.4 \\
\hline 9 & -57.0 & -79.0 & -2.7 & -19.7 & -10.4 & -23.1 & -5.1 & 3.4 \\
\hline 10 & -50.3 & -75.0 & -2.6 & -17.3 & -4.5 & -23.9 & -5.3 & 2.7 \\
\hline
\end{tabular}

Source: Authors' calculations using data from the U.S. Bureau of the Census as described in appendix A; International Labour Office (1993).

a. Figures are U.S. exports to partner countries minus U.S. imports from partner countries divided by the sum of these two flows.

b. Relative wages are foreign wages as a percent of U.S. wage.

sity with the United States are smaller. In that case, the United States has roughly balanced trade in goods made by high-skilled labor and lowskilled labor.

Table 7 also shows a finer disaggregation of trading partners, according to average wages in the partner countries. As expected, the pattern of trade varies systematically according to the average wage in the partner country, since the average wage presumably proxies for the skill intensity of the partner economy. For very low-wage (and presumably low-skilled) partners, the United States has large net deficits in low-skill industries and net surpluses in high-skill industries. As wages in the partner country rise, the net surpluses in the high-skill industries tend to remain (except for the most skill-intensive trade with countries whose wages equal $25-50$ percent of U.S. wages), but the deficits get larger in the middle deciles and fall in the low-skill deciles for high-wage countries. With wealthy partners (whose wages exceed 75 percent of those in the United States), the United States actually runs trade surpluses in goods made by low-skilled labor (deciles 9 and 10) and large deficits in goods in the middle range (deciles 4-8).

Table 8 shows the same data in a slightly different form. It shows the share of trade (both exports and imports) of partner countries according 
Table 8. U.S. Imports and Exports by Skill Decile and Relative Wage in Partner Country, 1990

Percent

\begin{tabular}{|c|c|c|c|c|c|}
\hline \multirow{2}{*}{$\begin{array}{c}\text { Trade } \\
\text { category } \\
\text { and skill } \\
\text { decile }\end{array}$} & \multicolumn{5}{|c|}{ Relative wage of partner country ${ }^{\mathrm{a}}$} \\
\hline & $\begin{array}{c}0-10 \\
\text { percent }\end{array}$ & $\begin{array}{c}10-25 \\
\text { percent }\end{array}$ & $\begin{array}{c}25-50 \\
\text { percent }\end{array}$ & $\begin{array}{c}50-75 \\
\text { percent }\end{array}$ & $\begin{array}{l}75 \text { percent } \\
\text { and over }\end{array}$ \\
\hline \multicolumn{6}{|c|}{ Share of imports ${ }^{b}$} \\
\hline 1 & 4.8 & 5.5 & 18.0 & 9.5 & 10.4 \\
\hline 2 & 1.9 & 5.2 & 2.8 & 20.0 & 12.3 \\
\hline 3 & 9.1 & 18.7 & 13.0 & 15.3 & 13.3 \\
\hline 4 & 12.5 & 10.6 & 9.9 & 12.6 & 8.0 \\
\hline 5 & 13.9 & 13.8 & 10.7 & 5.0 & 14.6 \\
\hline 6 & 5.6 & 6.5 & 7.1 & 7.0 & 5.5 \\
\hline 7 & 6.7 & 7.1 & 6.8 & 7.9 & 3.3 \\
\hline 8 & 4.8 & 14.9 & 4.5 & 8.0 & 29.6 \\
\hline 9 & 20.2 & 10.8 & 12.7 & 6.4 & 1.2 \\
\hline 10 & 20.7 & 7.0 & 14.6 & 8.2 & 1.8 \\
\hline \multicolumn{6}{|c|}{ Share of exports ${ }^{c}$} \\
\hline 1 & 8.2 & 7.3 & 11.5 & 16.4 & 14.0 \\
\hline 2 & 32.7 & 18.8 & 23.8 & 34.7 & 22.2 \\
\hline 3 & 29.6 & 25.7 & 27.7 & 18.7 & 17.6 \\
\hline 4 & 5.6 & 7.9 & 6.5 & 6.6 & 6.9 \\
\hline 5 & 8.7 & 14.0 & 11.9 & 10.2 & 11.0 \\
\hline 6 & 2.7 & 5.9 & 2.8 & 2.5 & 4.2 \\
\hline 7 & 2.7 & 4.3 & 2.5 & 3.1 & 3.8 \\
\hline 8 & 3.4 & 11.3 & 9.4 & 3.0 & 15.3 \\
\hline 9 & 2.7 & 2.1 & 1.8 & 1.8 & 2.1 \\
\hline 10 & 3.9 & 2.8 & 2.1 & 3.0 & 2.9 \\
\hline
\end{tabular}

Source: Authors' calculations using data from the U.S. Bureau of the Census as described in appendix A; International Labour Office (1993).

a. Relative wage is foreign wage as a percent of U.S. wage.

b. Shares of imports are U.S. imports in a decile for each wage group divided by total imports in that decile, by wage group.

c. Shares of exports are U.S. exports in a decile for each wage group divided by total exports in that decile, by wage group.

to skill decile. Once again, we see that the United States imports mostly non-skill-intensive products from the low-wage countries (especially deciles 9 and 10), while it imports skill-intensive goods from the highwage countries (mostly deciles $1-3$ ). Interestingly, the U.S. export pattern is fairly uniform across trading partners, with about 60 percent of exports in the three high-skill deciles and about 5 percent of exports in the two low-skill deciles (deciles 9 and 10).

In addition to showing the strength of the HOS approach, we also examine one of the key propositions of the "new trade theory": that U.S. 
trade with high-wage countries is intra-industry, while trade with lowwage countries is interindustry, based on factor proportions according to the HOS theory. For each of the partner countries $j$, we compute the Grubel-Lloyd index of intra-industry trade, given by ${ }^{21}$

$$
G L_{j}=\left[\left(X_{j}+M_{j}\right)-\left|X_{j}-M_{j}\right|\right] /\left(X_{j}+M_{j}\right) .
$$

The Grubel-Lloyd index varies between zero (no intra-industry trade) and one (only intra-industry trade). To take an example, the index for China is 0.16 and for Germany is 0.49 . We regress the Grubel-Lloyd index on the wage of country $j$ relative to the U.S. wage for 1990 . The results are very strong: low-wage countries have much more interindustry trade with the United States than do high-wage countries:

$$
G L_{j}=0.24+0.15\left(w_{j} / w_{U S}\right) .
$$

In equation 2 , the $\mathrm{R}^{2}$ equals 0.27 , with 102 observations and $t$-statistics in parentheses. Each 10 percentage point increase in the relative wage of country $j$ leads to an increase in $G L_{j}$ of 0.015 . Since trade with highwage countries is heavily intra-industry, we do not expect it to result in significant net job losses according to the skill intensity of production or to significant shifts in income distribution among workers of different skill levels. Trade with low-wage countries, however, will be more disruptive in terms of net shifts in employment and changes in wage differentials according to skill level.

\section{Trade, Skill Patterns, and Protection}

The distributional effects of trade can be mitigated by trade protection, though at the cost of economywide inefficiency. Since trade with low-wage countries puts downward pressure on the wages of unskilled workers in the United States, it is not surprising to find that U.S. trade policy is biased toward protecting less skill-intensive industries. It is not a question of whether the United States should protect low-skill sectors. The issue is one of degree.

Trade policy generally comes in two forms: tariffs and quantity restrictions. The quantity restrictions, in turn, take several forms: quotas, voluntary export restraints, orderly marketing agreements, and so forth.

21. Grubel and Lloyd (1975). 
Table 9. Trade Protection by Skill Decile, 1978 and 1991

Percent

\begin{tabular}{cccc}
\hline $\begin{array}{c}\text { Skill } \\
\text { decile }\end{array}$ & $\begin{array}{c}\text { Tariff } \\
\text { rate }\end{array}$ & $\begin{array}{c}\text { Tariff } \\
\text { equivalents } \\
\text { of quotas }\end{array}$ & $\begin{array}{c}\text { Total } \\
\text { protection }\end{array}$ \\
\hline Protection in 1978 & & \\
1 & 6.2 & 0.0 & 6.2 \\
2 & 5.5 & 0.0 & 5.5 \\
3 & 3.5 & 0.0 & 3.5 \\
4 & 5.5 & 1.5 & 7.0 \\
5 & 4.4 & 0.0 & 4.4 \\
6 & 5.5 & 4.3 & 9.8 \\
7 & 5.3 & 0.4 & 5.7 \\
8 & 2.5 & 0.0 & 2.6 \\
9 & 14.6 & 3.4 & 18.0 \\
10 & 14.1 & 5.4 & 19.5 \\
Protection in $1991^{\mathrm{b}}$ & & \\
1 & 2.4 & 0.0 & 2.4 \\
2 & 2.4 & 0.0 & 2.4 \\
3 & 2.3 & 0.0 & 2.3 \\
4 & 3.3 & 0.0 & 3.3 \\
5 & 2.8 & 0.0 & 2.8 \\
6 & 4.0 & 0.2 & 4.1 \\
7 & 4.5 & 0.3 & 4.8 \\
8 & 1.9 & 0.2 & 2.1 \\
9 & 13.3 & 10.7 & 24.0 \\
10 & 12.6 & 6.2 & 18.7 \\
\hline
\end{tabular}

Sources: Authors' calculations based on unpublished data provided by the U.S. International Trade Commission, U.S. International Trade Commission (1993), and Hufbauer, Berliner, and Elliott (1986).

a. Tariff rates are total duties collected divided by the customs value of imports. Tariff equivalents of quotas are the percentage equivalent of what quotas would be if they were changed into tariffs that afforded the same level of protection. Total protection is the sum of the two.

One way of measuring the overall effect of protection is through the price-gap method, applied by measuring the percentage gap observed between domestic prices and world prices (inclusive of shipping costs). The overall gap, $G$, is used to calculate the tariff equivalent of the quantity restrictions, according to the relationship $G=(1+t)(1+q)$, where $t$ is the observed ad valorem tariff and $q$ is the unobserved tariff equivalent of the quantity restriction. In table 9 , we present estimates from previous studies of tariffs and tariff equivalents by decile for 1978 and 1991 . (1991 was the only recent year for which we could locate a consistent set of tariff equivalents of quotas.)

We see that by 1978 , even before the sharp rise in trade with the developing countries, protection was highest in low-skill sectors: tariff 
rates were about 14 percent. Quotas were applied to the same sectors, particularly to apparel and textiles under the Multi-Fiber Arrangement. Import protection was also applied to basic steel (in decile 6) through a trigger price mechanism and to color televisions (in decile 4) through an orderly marketing agreement.

The basic pattern of protection was relatively stable between 1978 and 1991. The main changes between 1978 and 1991 were a cut in the already low tariff rates in deciles 1-8 and an apparent intensification of the effects of quotas on deciles 9 and 10. Tariff rates were also cut in deciles 9 and 10, although by less (in relation to 1978 rates) than in the other deciles. Therefore, the basic pattern of protection, which was heaviest for the less skill-intensive goods, was intensified. Note that steel protection (the trigger price mechanism) was also eliminated by 1991 and a newer quota restraint was considered by the U.S. International Trade Commission to be nonbinding.

\section{Trade and Employment Changes in U.S. Manufacturing, 1978-90}

We have shown, so far, that low-wage countries export less skillintensive products to the United States and import more skill-intensive products from the United States. This is the basis of the supposition that an increasing intensity of low-wage competition has reduced the employment in low-skill industries in the United States. The next step is to check whether the net trade deficit of the United States in low-skill industries has been widening over time. Since we want to see whether foreign competition is reducing domestic production, and therefore domestic employment, we now measure the net trade flows, $N$, relative to value-added, $V$, in sector $i$ :

$$
N_{i}=\left(X_{i}-M_{i}\right) / V_{i} .
$$

We want to check whether $N_{i}$ becomes more negative over time for lowskill deciles and more positive for high-skill deciles. We make the comparison for overall U.S. trade and separately for trade with developing countries and trade with developed countries.

In making this calculation, we take into account the prevailing patterns of tariff and quota protection in the United States in each year. Our 
Table 10. U.S. Net Exports as a Share of Value-Added by Skill Decile and Country Group, 1978-90 ${ }^{\text {a }}$

Percent

\begin{tabular}{|c|c|c|c|c|c|c|c|c|c|}
\hline \multirow[b]{2}{*}{$\begin{array}{c}\text { Skill } \\
\text { decile }\end{array}$} & \multicolumn{3}{|c|}{ All countries } & \multicolumn{3}{|c|}{ Developed countries } & \multicolumn{3}{|c|}{ Developing countries } \\
\hline & 1978 & 1990 & $\begin{array}{l}\text { Change, } \\
1978-90^{\mathrm{b}}\end{array}$ & 1978 & 1990 & $\begin{array}{l}\text { Change, } \\
1978-90^{\mathrm{b}}\end{array}$ & 1978 & 1990 & $\begin{array}{l}\text { Change, } \\
1978-90^{\mathrm{b}}\end{array}$ \\
\hline 1 & 2.2 & -2.1 & -4.4 & 0.7 & 0.0 & -0.6 & 1.5 & -2.2 & -3.7 \\
\hline 2 & 12.7 & 17.7 & 5.0 & 4.5 & 6.1 & 1.5 & 8.2 & 11.6 & 3.4 \\
\hline 3 & 9.1 & 1.1 & -8.0 & 4.4 & -0.9 & -5.3 & 4.7 & 2.0 & -2.7 \\
\hline 4 & -8.7 & -20.1 & -11.4 & -7.4 & -9.4 & -2.0 & -1.3 & -10.7 & -9.4 \\
\hline 5 & -10.6 & -13.6 & -3.1 & -6.4 & -8.1 & -1.7 & -4.2 & -5.5 & -1.3 \\
\hline 6 & -14.1 & -13.6 & 0.5 & -12.7 & -7.5 & 5.2 & -1.4 & -6.1 & -4.7 \\
\hline 7 & -3.4 & -7.4 & -4.0 & 0.9 & -1.9 & -2.8 & -4.3 & -5.5 & -1.2 \\
\hline 8 & -18.1 & -33.6 & -15.5 & -20.2 & -32.5 & -12.3 & 2.1 & -1.1 & -3.2 \\
\hline 9 & -17.2 & -43.9 & -26.8 & -4.6 & -2.7 & 1.9 & -12.5 & -41.2 & -28.7 \\
\hline 10 & -27.6 & -48.3 & -20.7 & -9.7 & -3.5 & 6.3 & -17.8 & -44.8 & -27.0 \\
\hline
\end{tabular}

Source: Authors' calculations using data from the U.S. Bureau of the Census as described in appendix A, NBER productivity data set with extensions, and U.S. International Trade Commission (1993).

a. Net trade flows relative to value-added are measured as U.S. exports to each country group minus U.S. imports from each country group for each decile, divided by the value-added of the industries in the decile. Imports, originally reported by customs value, have been increased by factors for c.i.f., tariffs, and tariff equivalents of quotas to create a landed value.

b. Changes in trade flows are percentage point changes and may not add completely because of rounding.

underlying trade data measure imports on a "customs value" basis, which means at the market price before costs of shipping (including transport and insurance) and before the imposition of tariff duties (or equivalent price increases induced by quotas). Thus, if $M_{i}$ is the dollar value of imports in the world market in decile $i$, then $M_{i}^{d}=M_{i}(1+$ cif $+t$ ) is the value of the imports in the domestic U.S. market, where cif is the shipping cost and $t$ is the total rate of protection.

We see that the simple ratio of $M_{i}$ to $V_{i}$ would understate the importance of the imported goods in the domestic market, since the world price of the imported goods would be lower than the domestic price. We need to compare the value of $M_{i}^{d}$ within the U.S. market to value-added. From this point forward, we therefore measure the net trade vector in U.S. domestic prices rather than in world prices when we are comparing the net trade to domestic value-added:

$$
N_{i}=\left(X_{i}-M_{i}^{d}\right) / V_{i} .
$$

The results are shown in table 10 . We see that net exports to developing countries fell in 9 out of 10 deciles (the exception being decile 2). The decline in net exports was greatest in the two low-skill deciles ( 9 and 10). Although declines are concentrated in the bottom five deciles, there 
Table 11. Change in Employment between 1978 and 1990 by Skill Decile and Employment Group

Percent $^{\text {a }}$

\begin{tabular}{cccc}
\hline Skill & $\begin{array}{c}\text { Non- } \\
\text { Production } \\
\text { employment }\end{array}$ & $\begin{array}{c}\text { All } \\
\text { production } \\
\text { employment }\end{array}$ & $\begin{array}{c}\text { Alle } \\
\text { employment }\end{array}$ \\
\hline 1 & -4.1 & 27.9 & 12.5 \\
2 & -7.2 & 9.2 & -0.7 \\
3 & -5.7 & 15.2 & 0.5 \\
4 & -18.0 & -4.1 & -14.4 \\
5 & -15.4 & 0.3 & -11.8 \\
6 & -20.0 & -7.1 & -17.4 \\
7 & -11.7 & 9.7 & -7.7 \\
8 & -14.6 & -2.3 & -12.5 \\
9 & -21.9 & -6.8 & -19.7 \\
10 & -29.1 & -13.0 & -27.3 \\
\hline
\end{tabular}

Source: Authors' calculations using data from the NBER productivity data set with extensions.

a. Employment percentages are computed as change in each employment group divided by the 1978 level of each employment group.

is a somewhat surprising fall in decile 4 and a relatively large drop in the highest-skill decile (1). For developed countries, the change in net exports is not as closely related to skill intensity, since skill intensities are comparable in the United States and developed country partners. Net exports rise in deciles 2, 6, 9, and 10 and fall in the others.

In table 11, we show for each decile the declines in employment during 1978-90 as a percent of 1978 employment levels. Every decile experiences a fall in the number of production workers, but the decline is clearly greatest in the low-skill sectors, as expected by the HOS approach (if increased low-wage trade is responsible). Interestingly, the number of nonproduction workers falls by a smaller proportion, or rises, in every decile. Put another way, the skill intensity of production (measured as the ratio of nonproduction to production workers) rises in every sector.

As a prelude to more formal measurements of the effects of trade on employment, we run some cross-sectoral regressions, shown in table 12, to explain changes in sectoral employment on some key structural variables. We measure the shares of capital, skilled workers, and unskilled workers in total sectoral value-added in 1978. We expect, on HOS grounds, that employment will fall by the largest proportion in sectors with high shares of capital (because capital is internationally mobile) and 
Table 12. Change in Employment as a Function of Sectoral Characteristics

\begin{tabular}{|c|c|c|c|c|c|c|}
\hline \multirow{3}{*}{$\begin{array}{l}\begin{array}{c}\text { Independent } \\
\text { variable }\end{array} \\
\text { Production worker } \\
\text { share }\end{array}$} & \multicolumn{6}{|c|}{ Dependent variable ${ }^{\mathrm{a}}$} \\
\hline & \multicolumn{2}{|c|}{ Total employment } & \multirow{2}{*}{$\begin{array}{c}\text { Production } \\
-2.07^{* *} \\
(-5.92)\end{array}$} & \multirow{2}{*}{$\begin{array}{c}\text { employment } \\
-2.76^{* *} \\
(-6.00)\end{array}$} & \multicolumn{2}{|c|}{$\begin{array}{c}\text { Nonproduction } \\
\text { employment }\end{array}$} \\
\hline & $\begin{array}{l}-2.38^{* *} \\
(-6.65)\end{array}$ & $\begin{array}{l}-2.67 * * \\
(-5.55)\end{array}$ & & & $\begin{array}{l}-2.08^{* *} \\
(-4.50)\end{array}$ & $\begin{array}{l}-2.20^{* *} \\
(-3.45)\end{array}$ \\
\hline Capital share & $\begin{array}{l}-1.64 * * \\
(-4.88)\end{array}$ & $\begin{array}{l}-1.91^{* *} \\
(-4.71)\end{array}$ & $\begin{array}{l}-1.41^{* *} \\
(-4.28)\end{array}$ & $\begin{array}{l}-1.95^{* *} \\
(-5.04)\end{array}$ & $\begin{array}{l}-1.45^{* *} \\
(-3.32)\end{array}$ & $\begin{array}{l}-1.57 * * \\
(-2.93)\end{array}$ \\
\hline R\&D & . & $\begin{array}{c}-2.17 \\
(-1.22)\end{array}$ & $\ldots$ & $\begin{array}{c}-4.23^{*} \\
(-2.51)\end{array}$ & $\cdots$ & $\begin{array}{c}-0.71 \\
(-0.30)\end{array}$ \\
\hline Constant & $\begin{array}{l}1.48^{* *} \\
(5.34)\end{array}$ & $\begin{array}{l}1.75^{* *} \\
(4.77)\end{array}$ & $\begin{array}{l}1.22 * * \\
(4.49)\end{array}$ & $\begin{array}{l}1.78^{* *} \\
(5.11)\end{array}$ & $\begin{array}{l}1.42^{* *} \\
(3.96)\end{array}$ & $\begin{array}{l}1.52^{* *} \\
(3.15)\end{array}$ \\
\hline $\begin{array}{l}\text { Addendum } \\
\overline{\mathrm{R}}^{2}\end{array}$ & 0.25 & 0.24 & 0.21 & 0.25 & 0.13 & 0.11 \\
\hline $\begin{array}{l}\text { Number of } \\
\text { observations }\end{array}$ & 131 & 108 & 131 & 108 & 131 & 108 \\
\hline
\end{tabular}

Sources: Authors' regressions based on NBER productivity data set with extensions, U.S. Bureau of the Census (1981), and U.S. Federal Trade Commission (1985). One asterisk ${ }^{*}$ ) denotes significance at the 5 percent level. Two asterisks $\left({ }^{* *}\right)$ denote significance at the 1 percent level. Numbers in parentheses are $t$-statistics.

a. Dependent variable is percentage change from 1978 to 1990.

high shares of unskilled workers. This result is borne out convincingly in the data. The share of production-worker compensation in value-added, and the share of capital in value-added, had a significant negative effect on employment growth during $1978-90$ for every category of employment: total, production and nonproduction. Employment fell most sharply in low-skill sectors and capital-intensive sectors, and least sharply in high-skill sectors.

We also add a proxy of research and development (R\&D) intensity (the share of R\&D expenditures as a proportion of total sales and transfers in 1977) to see whether R\&D-intensive sectors had especially large declines in employment. The $R \& D$ variable is estimated to have a negative effect on the change of production employment and a small insignificant effect on the number of nonproduction workers. This is indirect evidence in favor of the proposition that the rising ratio of nonproduction to production workers is associated with technological change resulting from $R \& D$ spending.

\section{Decomposition of Employment Changes Resulting from Trade}

We now turn to a more formal estimate of the relationship between trade and employment in the United States. To calculate the effects of 
increasing import penetration on employment, we postulate a counterfactual case in which import penetration (as a percent of final demand) does not increase after 1978. For the same level of final demand in 1990, and the same level of imports relative to final demand, there would have to be more domestic output and employment in order to satisfy demand. The increase in employment resulting from the counterfactual assumption about imports might be considered the amount of job loss that resulted from increased net imports between 1978 and 1990. Alternatively, we can say that our method calculates the labor content of the net trade flows resulting from the shift in the ratio of net trade to final demand between 1978 and 1990.

We proceed as follows. We let $D_{i}$ signify the amount of (real) final demand for output of sector $i$. This final demand can be satisfied by domestic production, which we signify as $Q_{i}^{F}$, or by net imports, which we signify as $N_{i}\left(=M_{i}^{d}-X_{i}\right)$ :

$$
D_{i}=Q_{i}^{F}+N_{i}
$$

Obviously, $Q_{i}^{F}=D_{i}-N_{i}$.

Domestic production of final goods in sector $i$ requires inputs from all of the other sectors, according to the input-output linkages of the economy. Let $\boldsymbol{\Omega}$ be the matrix that links the vector of total output $\mathbf{Q}$ (including final and intermediate uses) to the vector of final goods production:

$$
\mathbf{Q}=\mathbf{\Omega} \mathbf{Q}^{F} .
$$

The $i$ th element of $\mathbf{Q}$ is the total production of sector $i$ (measured by total shipments). The $i$ th element of $\mathbf{Q}^{F}$ is $Q_{i}^{F}$, the output meeting final demand in sector $i$. We can now write the change in domestic production $(\delta \mathbf{Q})$ as a function of changes in final demand $(\delta D)$ and changes in net imports $(\delta \mathbf{N})$. In each case, we use the input-output system to measure the direct plus the indirect effects:

$$
\delta \mathbf{Q}=\boldsymbol{\Omega}(\delta \mathbf{D})-\boldsymbol{\Omega}(\delta \mathbf{N}) .
$$

We do not actually observe final demand for each sector $i$. Instead, we observe total shipments for each sector, which include shipments for intermediate use as well as shipments for final demand. We therefore define $\mathbf{D}$ indirectly, by using the inverse of the input-output table, calculating $\mathbf{Q}^{F}$ as $\left(\boldsymbol{\Omega}^{-1}\right) \mathbf{Q}$ and then defining $\mathbf{D}$ as $\mathbf{Q}^{\boldsymbol{F}}+\mathbf{N}$. 
Now we construct the counterfactual. We define the ratio of net imports to final demand:

$$
n_{i}^{78}=N_{i}^{78} / D_{i}^{78} .
$$

We also define a counterfactual level of 1990 net imports for sector $i$, $N_{i}^{c}$, as the level that would preserve the same ratio of net imports to final demand:

$$
N_{i}^{c}=n_{i}^{78} D_{i}^{90} .
$$

For an unchanged level of final demand in 1990, we calculate the output effects of having the counterfactual level of net imports rather than the actual level of 1990 . We define $\delta N_{i}^{90}=N_{i}^{c}-N_{i}^{90}$. Then, using equation 6 we have

$$
\delta \mathbf{Q}^{90}=\mathbf{\Omega} \delta \mathbf{N}^{90} .
$$

We assume that average labor productivity within each sector in 1990 (measured as output per production worker and output per nonproduction worker) is unaffected by the counterfactual, so that percentage changes in production employment and nonproduction employment are equal to percentage changes in output, $\delta \mathbf{L}^{90} / \mathbf{L}^{90}=\delta \mathbf{Q}^{90} / \mathbf{Q}^{90}$. We multiply this percentage change by 1990 employment levels to get the counterfactual employment change in levels, $\left(\delta \mathbf{Q}^{90} / \mathbf{Q}^{90}\right) \mathbf{L}^{90}=\delta \mathbf{L}^{90}$. We then measure that level change relative to the 1978 base-year level of employment in each sector, $\delta \mathbf{L}^{90} / \mathbf{L}^{78}$, since we are interested in the effects of trade on the percentage decline of employment between 1978 and 1990.

The results are shown in table 13 . While we actually perform the counterfactual exercise using 51 manufacturing sectors (according to two-digit classifications used by the Department of Commerce in calculating the input-output matrix), we summarize the results according to our 10 production deciles. According to our counterfactual, the rise in net imports after 1978 has resulted in a significant loss of employment: 7.2 percent of production workers and 2.1 percent of nonproduction workers (measured relative to 1978 employment levels). Put another way, these proportions represent the factor content of the increased net imports after 1978.

Shifts in trade with the developed countries had almost no net effect on employment: production employment fell by 1.0 percent while nonproduction employment rose by 2.2 percent (as a result of increased 
Table 13. Accounting for Trade Effects on U.S. Employment

Percent

\begin{tabular}{cccc}
\hline & \multicolumn{3}{c}{$\begin{array}{c}\text { Change in employment } \\
\text { by country group }{ }^{\mathrm{a}}\end{array}$} \\
\cline { 2 - 4 } Skill decile & $\begin{array}{c}\text { Developing } \\
\text { country } \\
\text { trade }\end{array}$ & $\begin{array}{c}\text { Developed } \\
\text { country } \\
\text { trade }\end{array}$ & All trade \\
\hline 1 & 0.2 & 12.2 & 12.3 \\
2 & -0.9 & 0.9 & 0.0 \\
3 & -2.8 & -1.7 & -4.4 \\
4 & -2.3 & 2.9 & 0.5 \\
5 & -2.0 & -1.6 & -3.6 \\
6 & -5.5 & -2.4 & -7.9 \\
7 & -5.2 & -1.4 & -6.6 \\
8 & -2.6 & -2.1 & -4.7 \\
9 & -3.4 & -6.7 & -10.1 \\
10 & -23.5 & -3.6 & -27.1 \\
Addendum & & & \\
All manufacturing & -5.7 & -0.2 & -5.9 \\
Production $^{\mathrm{b}}$ & -6.2 & -1.0 & -7.2 \\
Nonproduction $^{\mathrm{b}}$ & -4.3 & 2.2 & -2.1 \\
\hline
\end{tabular}

Sources: Authors' counterfactual calculations described in the text and based on NBER productivity data set.

a. Import figures, originally reported on a customs value basis, have been increased by factors for c.i.f., tariffs, and tariff equivalents of quotas.

b. Denominator is total manufacturing employment for the specific employment group in 1978 .

skill-intensive exports), with an overall negative effect on employment of just 0.2 percent. Trade with developing countries therefore accounts for almost all of the net job losses. The overall effect of developing country trade, a decline in employment of 5.7 percent, is divided between a drop in production employment of 6.2 percent and a drop in nonproduction employment of 4.3 percent. Interestingly, trade with both developed and developing countries produced a relatively larger drop in employment of low-skilled workers. It is clear from the table that low-skill industries (high deciles) have the biggest proportionate drop in employment arising from increased import penetration. Only decile 1 records a rise in employment owing to trade.

In table 14, we report the overall percentage employment losses by two-digit manufacturing sectors (1978-90) and compare them with the counterfactual: the percentage change in 1990 employment relative to actual 1978 levels as a result of the counterfactual trade structure. We see that the counterfactual pattern of employment changes is correlated 
Table 14. Employment Changes by Two-Digit SIC Industry Group

\begin{tabular}{|c|c|c|c|}
\hline $\begin{array}{l}\text { SIC } \\
\text { two- } \\
\text { digit } \\
\text { code }^{\mathrm{a}}\end{array}$ & Industry & $\begin{array}{c}\text { Actual } \\
\text { employment } \\
\text { change }^{\mathrm{b}}\end{array}$ & $\begin{array}{l}\text { Counter- } \\
\text { factual } \\
\text { change }^{\mathrm{c}}\end{array}$ \\
\hline 20 & Food and kindred products & 5.0 & 0.8 \\
\hline 21 & Tobacco products & 30.8 & -8.3 \\
\hline 22 & Textile mill products & 28.5 & 54.7 \\
\hline 23 & Apparel, other textiles & 23.5 & 25.9 \\
\hline 24 & Lumber and wood products & 4.1 & -4.3 \\
\hline 25 & Furniture and fixtures & -3.8 & 6.1 \\
\hline 26 & Paper and allied products & 1.3 & 0.5 \\
\hline 27 & Printing and publishing & -34.3 & 0.4 \\
\hline 28 & Chemicals, allied products & 6.2 & 2.8 \\
\hline 29 & Petroleum and coal products & 18.4 & -0.7 \\
\hline 30 & Rubber, misc. plastics & -9.8 & 2.3 \\
\hline 31 & Leather, leather products & 51.8 & 32.1 \\
\hline 32 & Stone, clay, glass products & 15.2 & 3.2 \\
\hline 33 & Primary metal industries & 36.7 & 6.8 \\
\hline 34 & Fabricated metal products & 8.1 & 1.3 \\
\hline 35 & Machinery, except electric & 15.6 & -3.0 \\
\hline 36 & Electric, electronic equipment & 1.1 & 0.6 \\
\hline 37 & Transportation equipment & 7.6 & 3.3 \\
\hline 38 & Instruments, related products & 0.1 & 2.0 \\
\hline 39 & Miscellaneous manufacturing & 13.6 & 24.4 \\
\hline
\end{tabular}

Sources: Authors' counterfactual calculations described in the text and based on NBER productivity data set.

a. Industry classifications are based on U.S. Office of Management and Budget (1972).

b. Actual change is percentage change of all manufacturing employment from 1978 to 1990.

c. Counterfactual change is computed by assuming a 1990 trade structure equal to that of 1978 , with imports, originally valued at customs value, increased by factors for c.i.f., tariffs, and tariff equivalents of quotas.

with the actual percentage drop in employment during the 1978-90 period $(r=0.47$, significant at 0.05$)$. It is clear, however, that certain industries experience large drops in employment that are essentially unrelated to trade shifts (such as primary metals, which are mainly the steel industry, and coal products).

In table 15, we look at the sectoral distribution of the overall manufacturing employment losses. Rather than measuring the drop in employment as a percent of the base year employment in the sector, we measure the drop in employment in each industry between 1978 and 1990 as a percent of the total drop in manufacturing employment between 1978 and 1990. (The negative values for industries 25,27 , and 30 signify employment increases.) We also measure the counterfactual drop in employment in each sector as a proportion of the aggregate drop in employment 
Table 15. Distribution of Employment Changes and Certifications under the U.S. Trade Adjustment Assistance Program by Industry Group

Percent

\begin{tabular}{|c|c|c|c|c|}
\hline \multirow{2}{*}{$\begin{array}{l}\text { SIC } \\
\text { two- } \\
\text { digit } \\
\text { code }\end{array}$} & \multirow[b]{2}{*}{ Industry ${ }^{\mathrm{a}}$} & \multicolumn{2}{|c|}{$\begin{array}{l}\text { Distribution of } \\
\text { employment change }\end{array}$} & \multirow{2}{*}{$\begin{array}{l}\text { Distribution } \\
\text { of certifica- } \\
\text { tions } \mathbf{s}^{\mathrm{c}}\end{array}$} \\
\hline & & Actual & $\begin{array}{l}\text { Counter- } \\
\text { factual }\end{array}$ & \\
\hline 20 & Food and kindred products & 4.7 & 1.1 & 0.5 \\
\hline 21 & Tobacco products & 1.1 & -0.4 & 0.0 \\
\hline 22 & Textile mill products & 10.8 & 30.3 & 1.5 \\
\hline 23 & Apparel, other textiles & 22.6 & 36.6 & 14.9 \\
\hline 24 & Lumber and wood products & 1.7 & -2.6 & 1.1 \\
\hline 25 & Furniture and fixtures & -1.1 & 2.6 & 0.8 \\
\hline 26 & Paper and allied products & 0.5 & 0.3 & 0.4 \\
\hline 27 & Printing and publishing & -23.8 & 0.4 & 0.2 \\
\hline 28 & Chemicals, allied products & 3.2 & 2.1 & 1.6 \\
\hline 29 & Petroleum and coal products & 1.6 & 0.1 & 0.2 \\
\hline 30 & Rubber, misc. plastics & -4.4 & 1.5 & 3.1 \\
\hline 31 & Leather, leather products & 7.6 & 6.9 & 9.3 \\
\hline 32 & Stone, clay, glass products & 5.9 & 1.8 & 2.2 \\
\hline 33 & Primary metal industries & 27.1 & 7.4 & 18.1 \\
\hline 34 & Fabricated metal products & 8.5 & 1.9 & 4.3 \\
\hline 35 & Machinery, except electric & 21.1 & -6.0 & 12.2 \\
\hline 36 & Electric, electronic equipment & 1.3 & 1.1 & 11.4 \\
\hline 37 & Transportation equipment & 8.1 & 5.2 & 13.4 \\
\hline 38 & Instruments, related products & 0.0 & 0.9 & 2.7 \\
\hline 39 & Miscellaneous manufacturing & 3.4 & 8.9 & 0.2 \\
\hline
\end{tabular}

Sources: Authors' counterfactual calculations described in the text and based on NBER productivity data set; Bednarzik (1993, table 5).

a. Industry classifications are based on U.S. Office of Management and Budget (1972).

b. Employment changes are actual or counterfactual employment change for the industry divided by actual or counterfactual employment change in all manufacturing.

c. Share of certifications is the percent distribution by industry of worker certifications under the Trade Adjustment Assistance Program.

under the counterfactual. The correlation of the actual and counterfactual distributions is $r=0.41$ (significant at 0.07 ). The correlation between the actual distribution and the counterfactual distribution resulting from developing country trade is $r=0.46$ (significant at 0.04 ). We see, once again, that the counterfactual does not account for job losses in primary metals or in machinery. Nor does it predict the large employment gains in publishing.

We also compare the distribution of overall employment losses (both actual and counterfactual) with a direct empirical indicator of the distribution of job losses from trade competition, shown in the final column 
of the table. Under the Trade Adjustment Assistance Program, workers who petition for relief must be certified as having lost their jobs as a result of international trade. ${ }^{22}$ We report the percentage of all certified workers according to their sector of previous employment. We see, for example, that a high proportion of certifications came in apparel, leather and leather products, primary metals, machinery, electrical equipment, and transport equipment. We can see that the distribution of certifications is highly correlated with the distribution of actual employment losses ( $r=0.71$, significant at the 0.01 level) and counterfactual employment losses resulting from developing country trade $(r=0.43$, significant at the 0.06 level). These results bolster the idea that much of the employment decline between 1978 and 1990 was linked to shifts in international trade patterns.

\section{Additional Employment Effects of Trade?}

Wood has suggested that perhaps the employment loss as measured by trade shifts understates the full implications of trade. ${ }^{23}$ First, he argues that the employment displaced by low-wage trade in a particular sector is likely to be much less skill intensive than average employment in the sector. For example, if some toys are non-skill-intensive stuffed animals and others are skill intensive, it will probably be the less skillintensive production that will be displaced by trade with developing countries. Measuring the employment displacement by the average skill intensity in the sector could therefore be misleading.

We tried to test this important hypothesis by examining two variables. If Wood is correct, we would expect to see an especially large rise in the skill intensity of production in sectors that have been hard-hit by developing country trade, because these sectors would be shedding production workers relative to nonproduction workers. We could not find this effect in the data. If anything, the opposite seems to be true: the rise in the skill intensity of production is slightly greater for the high-skill sectors than for the low-skill ones.

As a second approach, we might find an especially large measure of total factor productivity (TFP) in sectors that are shrinking because of

22. See Bednarzik (1993) for details.

23. Wood (1994). 
developing country trade, since these sectors would be shedding the lowest-productivity workers in the face of international competition. This would show up erroneously as a rise in total factor productivity. Here, we did find some evidence. During 1960-78, TFP growth was slightly lower, on average, in low-skill sectors than in high-skill ones; during 1978-89, however, it was slightly greater in low-skill sectors. In fact, according to our regression estimates, decile 1 experienced an average slowdown in TFP growth of 0.8 percent a year, when comparing TFP growth during 1960-78 and 1978-89; decile 10, on the other hand, experienced a slight acceleration of TFP growth of 0.1 percent a year. (In the regression, we also add dummy variables for two large TFP outliers: computers and cigarette production.) We cannot verify that the relatively greater TFP growth in low-skill sectors is due to intense import competition in the low-skill sectors. If it is, it would add another few percentage points to the overall negative effects of trade on employment.

\section{Implications of Trade Shifts for Wage Inequality}

The implications of trade shifts for absolute and relative wages in the United States is a far more difficult issue than the effects of trade on employment. With respect to employment, we can measure the factor content of trade and estimate the employment implications of alternative trade vectors. With wages, however, we must confront several complicating factors: (1) manufacturing is a relatively small part of the aggregate labor force, just 16 percent of nonagricultural employees in 1993; (2) labor markets are segmented, both within manufacturing and between manufacturing and nonmanufacturing, so that earnings depend on sector-specific rents, union premia, and short-term disequilibria that may take several years to resolve; and (3) analysis should be based, in part, on micro data, to account for detailed worker characteristics together with industry characteristics. It is impossible, therefore, to look at manufacturing data alone and judge the full consequences for wages in the U.S. labor market.

We can make the following general points, however. Even if there are large employment shifts because of changes in net imports, the employment effects will cause a widening of income inequalities only if there are significant differences in the employment consequences for 
low-skilled and high-skilled workers. Of course, we have found important differences, with the demand for low-skilled workers falling by more than the demand for high-skilled workers, but just by a few percentage points.

To the extent that the manufacturing labor force is segmented from the rest of the economy, such differential demands for skilled and unskilled labor could have contributed significantly to a widening of wage inequalities within manufacturing but not within other sectors of the economy. However, if the manufacturing labor force is highly integrated with the rest of the economy, even a 10 percent drop in the relative demand for unskilled manufacturing labor would have only a small effect on the overall demand for unskilled labor, since low-skill manufacturing employment is such a small proportion of total low-skill employment. For this reason, it is difficult to see how the observed effects of trade could be sufficient to account for the bulk of the widening income inequality.

Even though trade is unlikely to explain all of the rise in wage inequality, the circumstantial evidence also points to a significant role for trade. First, the timing is right. The widening of the skilled-unskilled wage differential started in the late 1970s and early 1980s, just at a time when lowwage import competition was rising significantly. (Remember that, until the late 1970s, the rise of European and Japanese wages meant that lowwage import competition was actually declining, thus boosting the wages of unskilled labor relative to those of skilled labor.) Second, models in which labor markets are segmented at the level of individual manufacturing sectors suggest that wages in export sectors have done better than wages in import-competing sectors. ${ }^{24}$ Since the export sectors are skill-intensive, high-wage sectors, a pattern in which export workers gain while import-competing workers lose would be consistent with widening wage inequality.

Lawrence and Slaughter rightly emphasize that, according to the HOS model, changing trade patterns affect relative wages by changing the relative output prices of low-skill and high-skill goods. Trade liberalization in the U.S. partner countries should lead not only to a displacement of U.S. low-skilled workers from import-competing sectors but also to a decline in the relative price of the non-skill-intensive, import-

24. See Revenga (1992) and Bernard and Jensen (1993). 
competing goods. It is this decline in the price of non-skill-intensive goods that causes the wage of low-skilled labor to decline according to the HOS model.

Thus, we cannot go directly from the shifts in net trade, and the resulting shifts in net employment, to shifts in relative wages. When we calculate our counterfactual and find that labor demand for low-skilled workers has fallen by more than that for high-skilled workers, we can take the step of linking this to relative wages (within the HOS model) only if the trade flows are also linked to relative output price changes. In a very useful theoretical article, Alan Deardorff and Robert Staiger show conditions under which changes in the factor content of trade are linked in a straightforward way to changes in relative output prices, and therefore to changes in relative factor wages. ${ }^{25}$ For example, they show that the factor content of trade (as we have measured it) can be used to describe the wage effects of increased trade when utility and production functions are Cobb-Douglas. ${ }^{26}$

In our context, the key question is whether the greatly increased trade with East Asia, Brazil, and Mexico led to a lowering of the relative prices of the less skill-intensive goods exported by these countries, thereby reducing the wages of low-skilled workers as predicted by the HOS model. This question is harder to answer than one would suppose. Data on trade prices are notoriously problematic, since there are great difficulties in controlling for quality, product mix, and effective market prices given the extent of international trade that actually represents the international transfer of goods within multinational companies (as described in the next section).

Moreover, according to HOS theory, we are not interested in output prices as such, but in output prices adjusted for total factor productivity

25. Deardorff and Staiger (1988).

26. Specifically, they compare relative wages under autarky and free trade. They show that the factor content of the trade vector under free trade can be used to assess the shift in relative wages between autarky and free trade. A country that exports skill-intensive goods and imports labor-intensive goods under free trade (as does the United States) can be shown to have a higher relative wage of labor-intensive goods under autarky. This analysis provides a link between the labor market studies of the factor content of trade, and predictions about the effects of trade on relative wages. Of course, as Krugman and Slaughter, as well as Leamer and we, have stressed, the mediating variable is the shift in relative product prices as a result of trade liberalization, since relative wages are linked one for one with relative product prices. 
in the sector (what trade economists call "effective prices"). Suppose that a sector experiences a 10 percent fall in relative prices but also experiences a 10 percent rise in total factor productivity that is not enjoyed by other sectors. The price decline would diminish the marginal revenue product of factors in that sector; the productivity increase would raise the marginal revenue product of factors in that sector. In fact, the two effects would exactly offset each other, so that there would be no overall effect on the marginal revenue product of the factors in the sector and no change in the factor rewards in the overall economy. Effective prices are generally measured as

$$
P_{i}^{e}=P_{i} T F P_{i},
$$

where $T F P_{i}$ is an index of total factor productivity in sector $i$. Of course, since TFP is notoriously hard to measure, this adds another degree of measurement difficulty.

Lawrence and Slaughter first examine the changes in actual prices (not adjusting for TFP) and then the changes in effective prices (multiplying prices by an index of TFP). With actual prices, they conclude that low-skill sectors have not experienced a fall in relative prices. That is, according to Lawrence and Slaughter, the increased trade from East Asia and Latin America has not resulted in a decline in relative prices of textiles, footwear, and other goods exported by these countries. This is one of the main reasons that these authors tend to downplay the HOS effects in the U.S. economy over the past 15 years. When we reexamine the price evidence, however, we find reason to believe that the HOS effects are at work vis-à-vis prices, just as they are vis-à-vis employment patterns, though admittedly the results are less than robust.

Lawrence and Slaughter make their claim based on industry import and export price indexes provided by the U.S. Bureau of Labor Statistics. While these price indexes are better indicators of trade prices than the more traditional unit-value indexes, the price indexes are surely inadequate for drawing any definitive conclusions. The price indexes are available for the whole 1980-90 period for fewer than one-fourth of the industries, specifically 30 (three-digit SIC) industries out of more than 130 industries. For another 20 industries, the data start sometime in the 1981-86 period. In some of their graphs, Lawrence and Slaughter combine data with different starting points, even though this is likely to intro- 
duce significant error into the data. ${ }^{27}$ We also think that they should have separated the effects of computer prices from the other sectors. The relative prices of computers fell sharply during the decade, matching extraordinary productivity increases. The exact measurement of these price and productivity changes is highly problematic, so that it is important that these changes do not overwhelm the message in the rest of the data. ${ }^{28}$

When we restrict our attention to the few industries for which the import price data are available starting in 1980 , we find that the relative prices of the less skill-intensive goods fell, just as one would expect from the increased trade with low-wage countries, but the relationship is very weak and not statistically significant. The relevant regression is shown in table 16. Regression equation 16-1 regresses annual nominal price changes between 1980 and 1989 on the ratio of unskilled workers to total employment, using only those sectors for which import price data are available for the entire period and including a dummy variable for computers. The negative coefficient $(-0.02)$ means that the low-skill sectors had a decline in relative prices.

We can learn much more about relative price changes by using domestic price deflators from the U.S. Bureau of Economic Analysis. Such deflators are available for all years for all three-digit industries. We report the relationship of skill levels and relative prices using these data in regression 16-2 for average annual changes during 1978-89. As before, regression 16-2 regresses the change in relative prices on the ratio of unskilled workers to total employment, adding a dummy variable for computers. Again, we find that the relative price of non-skill-intensive goods fell during the $1980 \mathrm{~s}$. This time the effect on prices is statistically significant at the 0.05 level. According to the estimated coefficient, the average

27. Lawrence and Slaughter (1993) measure average annual nominal price changes for the various sectors from the first year of the data until 1991. Some data start in 1980, some in 1981, and so on. Since inflation was high in the early 1980s and lower in the mid-1980s, data that start early in the 1980 s will show a systematically higher annual average price change than price data that start later in the 1980s.

28. To see the measurement difficulties, compare the import price index for office and computing machines with the producer price index for the same sector (SIC 357). The import price index shows a 4.1 percent increase between 1980 and 1990, while the producer price index shows a 75.6 percent decrease in the decade, after taking account of quality improvements in domestically produced and shipped merchandise. 
Table 16. Regressions of Price Changes on Low Skill Intensities

\begin{tabular}{|c|c|c|c|c|c|c|c|}
\hline \multirow[b]{2}{*}{$\begin{array}{c}\text { Independent } \\
\text { variable }\end{array}$} & \multicolumn{7}{|c|}{ Dependent variable } \\
\hline & $\begin{array}{c}\text { Import } \\
\text { price } \\
16-1\end{array}$ & $\begin{array}{c}\text { Domestic } \\
\text { price, } \\
1978-89 \\
16-2\end{array}$ & $\begin{array}{c}\text { Domestic } \\
\text { price, } \\
1960-78 \\
16-3\end{array}$ & $\begin{array}{c}\text { Effective } \\
\text { price with } \\
\text { import } \\
\text { price } \\
16-4\end{array}$ & $\begin{array}{c}\text { Effective } \\
\text { price with } \\
\text { domestic } \\
\text { price, } \\
1978-89 \\
16-5\end{array}$ & $\begin{array}{c}\text { TFP, } \\
1960-78 \\
16-6\end{array}$ & $\begin{array}{c}T F P \\
1978-89 \\
16-7\end{array}$ \\
\hline Low skill intensity & $\begin{array}{c}-0.02 \\
(-0.62)\end{array}$ & $\begin{array}{c}-0.02 * \\
(-1.98)\end{array}$ & $\begin{array}{c}0.001 \\
(0.105)\end{array}$ & $\begin{array}{c}-0.01 \\
(-0.38)\end{array}$ & $\begin{array}{c}-0.01 \\
(-1.82)\end{array}$ & $\begin{array}{c}-0.01 \\
(-1.61)\end{array}$ & $\begin{array}{c}0.01 \\
(0.79)\end{array}$ \\
\hline Computer dummy & $\begin{array}{c}-0.02 \\
(-1.04)\end{array}$ & $\begin{array}{l}-0.21^{* *} \\
(-13.40)\end{array}$ & $\begin{array}{l}-0.07^{* *} \\
(-5.46)\end{array}$ & $\begin{array}{c}-0.08^{* *} \\
(4.14)\end{array}$ & $\begin{array}{l}-0.09^{* *} \\
(-8.04)\end{array}$ & $\begin{array}{l}0.06^{* *} \\
(4.83)\end{array}$ & $\begin{array}{l}0.12^{* *} \\
(8.77)\end{array}$ \\
\hline Constant & $\begin{array}{c}0.04 \\
(1.47)\end{array}$ & $\begin{array}{l}0.06^{* *} \\
(7.08)\end{array}$ & $\begin{array}{l}0.04^{* *} \\
(5.26)\end{array}$ & $\begin{array}{c}0.04 \\
(1.64)\end{array}$ & $\begin{array}{l}0.06^{* *} \\
(9.86)\end{array}$ & $\begin{array}{l}0.02^{* *} \\
(2.67)\end{array}$ & $\begin{array}{l}-0.001 \\
(-0.08)\end{array}$ \\
\hline$\frac{\text { Addendum }}{\overline{\mathrm{R}}^{2}}$ & -0.03 & 0.58 & 0.18 & 0.43 & 0.33 & 0.18 & 0.37 \\
\hline $\begin{array}{l}\text { Number of } \\
\text { observations }\end{array}$ & 30 & 131 & 131 & 30 & 131 & 131 & 131 \\
\hline
\end{tabular}

Sources: Authors' regressions using NBER productivity data set and import price indexes from the U.S. Bureau of Labor Statistics.

a. All variables except computer dummy are ratios, rather than percentages. Import price is the average annual change in the BLS import price index from 1980 to 1989 . Domestic price, 1978-89, is the average annual change in the value of shipments deflator from 1978 to 1989 . Domestic price, 1960-78, is the average annual change in the value of shipments deflator from 1960 to 1978. Effective price with import price is the sum of the average annual changes in the BLS import price index and total factor productivity from 1980 to 1989 . Effective price with domestic price, 1978-89, is the sum of the average annual changes in the value of shipments deflator and total factor productivity from 1978 to 1989 . TFP, 1960-78, is the average annual change in total factor productivity from 1960 to 1978 . TFP, $1978-89$, is the average annual change in total factor productivity from 1978 to 1989 . Low skill intensity ratio is the industry's ratio of production employees to total employees.

One asterisk $\left({ }^{*}\right)$ denotes significance at the 5 percent level. Two asterisks $\left({ }^{* *}\right)$ denote significance at the 1 percent level. Numbers in parentheses are $t$-statistics.

price of a good in decile 10 fell by 9 percent compared with the average price of a good in decile 1 during the 1978-89 period.

Our conclusion that price effects have been squeezing low-skill sectors after 1978 is strengthened if we look at how relative prices changed during 1978-89 compared with the changes during 1960-78. In the earlier period, the prices of non-skill-intensive goods actually rose slightly (though statistically insignificantly) relative to the prices of skill-intensive goods, as shown in regression 16-3. After 1978, the prices of nonskill-intensive goods fell in relative terms, as seen in regression 16-2. Thus, the behavior of prices after 1978 represents a shift in previous trends: this is consistent with the rise in low-wage trade competition after 1978. It is also consistent with the shift in wage inequality-declining in the 1960s and 1970s and rising in the 1980s.

After looking at actual prices, Lawrence and Slaughter also look at the behavior of "effective prices," as calculated in equation 10 by multi- 
plying the price index by an index of total factor productivity change. Once again, they use the Bureau of Labor Statistics data on trade prices in their calculations. They find that the effective prices (unlike actual prices) of less skill-intensive goods actually fell during the 1980s, but they now attribute this to the faster productivity growth of high-skill sectors rather than to shifts in market prices induced by trade. Once again, we have doubts about their conclusions.

In table 16, regression 16-4 reports our results using effective prices, based on the trade price data from the Bureau of Labor Statistics, but as before we restrict the observations to those available for the entire period 1980-89. We find that the relative effective price of non-skill-intensive goods declined but by less than relative actual prices. (The coefficient is now -0.01 , as opposed to -0.02 in regression 16-1.) In fact, TFP moved in the "wrong" direction for the Lawrence and Slaughter technology argument: TFP growth was less on average in high-skill industries than in low-skill industries during 1978-89, reversing the pattern of 1960-78, when the high-skill sectors had higher TFP growth on average. The same pattern is evident in regression 16-5, where we regress effective prices on the low-skill variable using the domestic price deflators. Again, the relative effective prices of the less skill-intensive goods decline during 1978-89 but by less than the decline of relative $a c$ tual prices (coefficient -0.01 rather than -0.02 ). (Remember, however, that we are using a dummy variable for one extreme outlier among the 131 sectors: the skill-intensive computer sector.) The TFP patterns are shown in regressions 16-6 and 16-7, in which we regress annual average TFP growth in the two periods on a measure of low skill intensity and a dummy variable for computers. The negative coefficient on the low-skill variable in regression 16-6 means that the low-skill sectors had lower TFP growth on average during 1960-78; the positive sign in regression 16-7 reflects the reversal of this pattern in the more recent period. Both regressions add a dummy variable for computers.

To sum up this complicated story, we can say the following. Relative prices of less skill-intensive goods declined after 1978, just as the HOS theory would predict. This is especially clear when we examine domestic price deflators that cover all of manufacturing, rather than import price indexes, which are available for the whole time period for only a small subset of manufacturing. Moreover, productivity changes after 1978 actually favor low-skilled workers, since TFP growth was fastest 
in low-skill sectors. These conclusions are reinforced when we compare trends during 1960-78 with those after 1978. In the earlier period, relative prices of less skill-intensive goods actually rose, while they fell after 1978. In the earlier period, TFP growth was fastest in high-skill industries, while it was fastest in low-skill industries after 1978. All said, the evidence points more toward shifts in trade and market prices than toward shifts in TFP growth as the relevant factor in widening wage inequalities after 1978.

Nonetheless, we must end this section with a note of caution. Although the results on prices are consistent with the role of trade in squeezing the wages of low-skilled workers, we have not found a large enough relative price effect to account for a significant widening of wage inequalities. Even if the prices of least skill-intensive manufactured goods fell by 10 percent relative to those of most skill-intensive ones, this is not enough to reduce the relative wages of low-skilled workers in the entire economy by 10 percent or more. No doubt, part of the problem is that our estimates of the relationship between relative prices and skill intensity are weakened by measurement errors in both the left- and right-hand-side variables of the regressions. We are measuring skill intensity with error and are certainly measuring output prices without adequate corrections for changes in quality and product mix.

\section{Biased Technical Change as a Factor in Job Losses}

Lawrence and Slaughter also point out that during the 1980s virtually every manufacturing sector increased the ratio of skilled to unskilled workers (that is, nonproduction to production workers), despite the fact that the relative wage of unskilled workers was falling. Evidently, $b i-$ ased technical change in the form of technical change that saves unskilled labor (inducing the substitution of skilled for unskilled workers) was at work alongside neutral growth in total factor productivity. This kind of technical change has been evident for nearly a hundred years, not just for the 1980s. In the postwar era, the proportion of nonproduction workers in total manufacturing employment increased steadily, from 16.6 percent in 1947, to 24.4 percent in 1960, 25.9 percent in 1970, 26.1 percent in 1978 , and 31.0 percent in $1990 .{ }^{29}$

29. U.S. Bureau of the Census (1962) and NBER productivity data set. 
The presence of this kind of technical change does not in any way diminish the independent importance of international trade in the 1980s. In fact, it may even strengthen the argument that international trade has played a key role over the past 15 years. Suppose, for example, that new computer technology has made it possible to perform every manufacturing process with half the number of unskilled workers than were formerly required. This would raise the ratio of skilled to unskilled workers, but it would also tend to reduce the wage gap between unskilled and skilled workers, since each unskilled worker would now have the effective labor power of two former unskilled workers. In this case, we would have the phenomenon observed between 1960 and 1978: a rising ratio of skilled to unskilled workers, combined with a falling wage gap. Therefore, technical change that saves unskilled labor, if it comes in the form just described, would not be enough to account for the observed trends in wage inequality. However, the combination of such technical change with a trade-induced fall in the relative price of non-skill-intensive production would explain a rising ratio of skilled to unskilled workers and a rising ratio of their wages. ${ }^{30}$

Leamer has recently carried out a formal exercise to see what the actual patterns of technical change that saves unskilled labor should have implied for U.S. wage differentials. ${ }^{31} \mathrm{He}$ shows for a particular specification of biased technical change that observed patterns of technical change by themselves should have led to a narrowing of wage inequality (assuming only technical change and no change in output market prices).

30. Consider a simple numerical example. Suppose that it initially takes two units of unskilled labor and one unit of skilled labor to produce good 1 (the less skill-intensive good), while it takes one unit of unskilled labor and two units of skilled labor to produce good 2 (the skill-intensive good). Prices of both goods are initially one. Wages of unskilled and skilled labor would then each be one-third. Now suppose that the labor requirement for unskilled labor falls by half for each good. The ratio of skilled to unskilled workers would double in each sector. If output prices were to remain unchanged, then the wage of unskilled labor would double (to two-thirds), while the wage of skilled labor would remain unchanged. Now suppose that this technical change occurs at the same time that the price of good 1 (the less skill-intensive good) falls to three-fourths as the result of international competition. Then, it is easy to check that the wage of unskilled labor would fall back to one-third, while the wage of skilled labor would rise to five-twelfths. Comparing the initial conditions with the final result (of both trade and technical change), we would observe the pattern seen in the United States: the ratio of skilled-to-unskilled labor would rise, together with the gap between the wages of the two groups.

31. Leameı (1994). 
Thus, Leamer indicates that non-skill-intensive technical change (in the form he specifies) does not explain the rising wage inequality by itself. Something else is probably at work. One of Leamer's candidates, and ours, is international trade. ${ }^{32}$

\section{U.S. Transnational Corporations and Import Competition}

We have seen that job losses in manufacturing are positively correlated with the capital intensity of production in manufacturing subsectors. Such evidence is consistent with the view that capital is internationally mobile and therefore not a restraining factor in manufacturing production in low-wage and, initially, capital-scarce economies. Indeed, many economists argue that capital outflows rather than intersectoral trade shifts place the greatest pressures on low-wage sectors in the United States. Capital outflows from the richer countries could reduce the capital stock, and thereby depress the marginal product of labor in the high-wage, capital-abundant economies, while raising the capital stock and the marginal product of labor in the low-wage, capitalscarce economies. The capital-intensive economy would undertake its low-skill production in the poorer country and pay for the imports with the earnings on the foreign investment.

There are few empirical studies of the overall effects of international capital flows on reallocating global production. Feldstein provides one of the few macroeconomic analyses. ${ }^{33}$ His regression results suggest that outbound foreign direct investment tends to reduce the source country's capital stock (rather than being offset by some other form of international capital flow). Feldstein's regression results are consistent with the view that foreign direct investment from the United States and other developed countries to the developing world is contributing to a net shift in the global capital stock toward the developing countries. Unfortunately, the analysis is not disaggregated enough (for example, to the level of manufacturing investment) to form a quantitative estimate

32. Our discussant, Robert Hall, importantly stressed to us that other specifications of biased technical change might well be consistent with rising rather than falling wage inequality. Still, no studies have yet demonstrated this link directly.

33. Feldstein (1994). 
of the effects of foreign direct investment on the U.S. manufacturing capital stock.

The linkages of trade and foreign investment are more complex than simply reallocating the site of production. Internationalization in the past two decades has meant three things: (1) greater flows of trade as a proportion of income; (2) greater flows of international capital, both in the form of foreign direct investment and, recently, in the form of portfolio investment in emerging markets; and (3) globally integrated production within transnational corporations. ${ }^{34}$ One implication of the third trend is that an increasing proportion of international trade is actually carried on within TNCs (as sales from an affiliate in one country to an affiliate or parent in another). ${ }^{35}$

As an example, in 1990 a remarkable 27.5 percent of U.S. exports to Mexico and 33.6 percent of imports from Mexico were actually sales between affiliates and parents operating in the two countries. If we measure TNC-based trade as all trade between a U.S.-affiliated company in Mexico and a U.S. resident company (not necessarily affiliated with the Mexican-based company), TNC-based trade as a proportion of total trade with Mexico was 33.6 percent for exports to Mexico and 36.5 percent for imports from Mexico. Note that a high proportion of all TNCbased trade is actually trade between affiliated companies. The effects of TNC-based trade integration tend to be deeper than simple trade liberalization, since foreign direct investment brings not only linkages in trade but also linkages in $\mathrm{R} \& \mathrm{D}$, technology, skills, and organizational patterns.

The role of TNC-based trade with the developing countries is likely to rise rapidly in the future. During the past decade, global foreign direct investment in developing countries has tended to grow much faster than international trade, which, in turn, has tended to grow faster than world income. Moreover, market liberalization in the developing world has included substantial liberalization of foreign direct investment as well as of international trade. The United Nations reports on the wide range of liberalizing measures and investment incentives for foreign direct investment undertaken by individual developing countries. ${ }^{36}$ The Uru-

34. For an excellent overview of these trends, see United Nations $(1992,1993)$.

35. For a brief case study of how internationalization proceeded in the 1980s in one major company, Xerox, see McGrath and Hoole (1992).

36. United Nations (1993). 
guay Round had a substantial focus on foreign investment liberalization and the ground rules of such investment, especially as part of the General Agreement on Trade in Services (GATS) and Trade-Related Investment Measures (TRIMs). Similarly, the North American Free Trade Agreement gives detailed, substantive protections to foreign direct investment within North America and especially liberalizes access of foreign investors to the Mexican economy. ${ }^{37}$

While it is beyond the scope of this paper to investigate the full implications of foreign direct investment for U.S. trade and employment patterns, we can at least ask when TNC-based trade increased, and whether there is evidence that it has added to the intensity of trade competition in the U.S. economy. To do this, we measure country $j$ 's two-way manufacturing trade with the United States that passes through TNCs as a proportion of all manufacturing trade between country $j$ and the United States:

$$
T N C_{j}=\left(X_{j}^{T N C}+M_{j}^{T N C}\right) /\left(X_{j}+M_{j}\right),
$$

where $X_{j}^{T N C}$ and $M_{j}^{T N C}$ are exports to U.S. affiliates and imports from U.S. affiliates, respectively. ${ }^{38}$ The results are shown in table 17 , with countries ranked by their extent of TNC trade with the United States.

The overall share of U.S. manufacturing trade that is TNC based actually declined slightly between 1977 and 1990 , from 20.5 percent to 18.4 percent. The decline occurred in trade with other developed countriesmost importantly Canada, the main trading partner of the United States. The share of developing country trade that was TNC based increased significantly between 1977 and 1990 , from 8.7 percent of trade to 13.4 percent of trade. Mexico is the prime example of an increase in TNCbased trade with the United States, with such trade rising from 13.9 percent of trade in 1977 to 30.0 percent of trade in 1990. The TNC-based trade of the United States with developing countries is concentrated in

37. NAFTA contains several provisions substantially strengthening the protections on foreign direct investment in Mexico. They include agreements for dispute resolution, such as international arbitration; most-favored-nation treatment for U.S. and Canadian investors in Mexico; guarantees of full and fair compensation for expropriated investments; and a widespread liberalization of access for foreign direct investors.

38. The definition of TNC-based trade from here onward includes all sales between U.S. resident firms and U.S. majority-owned affiliated firms operating in the partner country. The two firms do not themselves have to be affiliated with each other. In fact, the vast majority of TNC-based trade is actually between directly affiliated units. 
Latin America and East Asia. Unfortunately, we did not have available a breakdown of TNC trade by type of good.

Does TNC-based trade increase the overall amount of trade volume by facilitating an international division of labor among production units within the TNC? To investigate this, we estimate a standard "gravity equation" for the United States and 138 partner countries that predicts the volume of trade between the United States and the partner in 1990 as a function of the partner country's GDP per capita, and population, distance from the United States, as well as regional dummy variables to capture trade protectionism and an index of TNC trade. Our hypothesis is that countries with tighter TNC linkages with the United States, as measured by the index of TNC trade, will also have a larger volume of trade, controlling for other structural characteristics such as income levels, population, and distance.

The gravity equation for U.S. exports is estimated in the form

$$
\begin{aligned}
\log \left(X_{j}\right)= & \beta_{0}+\beta_{1} \log \left(Y_{j}\right)+\beta_{2} \log \left(N_{j}\right) \\
& +\beta_{3} \log \left(D_{j}\right)+\beta_{4} Z_{j}+\beta_{5} T N C_{j},
\end{aligned}
$$

where $Y_{j}$ is per capita GDP of the trading partner, $N_{j}$ is its population, $D_{j}$ is air distance from the partner's capital city to Chicago, $Z_{j}$ includes other characteristics (such as regional dummy variables), and $T N C_{j}$ is the transnational corporate trade variable. A similar equation is estimated for imports. Both equations are estimated on a cross-section of country data, separately for 1978 and 1990 . The TNC variable is available for only about 40 countries in our sample. For almost all of the other countries, the TNC-based trade is very small, though not necessarily zero, and is therefore not reported by the U.S. Department of Commerce. In a handful of cases, the data are not reported to preserve the confidentiality of individual companies. We treat the missing observations in two ways: either by dropping the countries for which TNC trade is not available or by imputing a value of zero for such countries. We report both cases. The estimates are shown in table 18 .

We see many important implications. As expected, the volume of trade is positively related to population, with (approximately) a unitary elasticity, and to partner per capita income, with an elasticity greater than one. A doubling of per capita income leads to more than a doubling of trade, presumably because U.S. trade with richer countries is based 
Table 17. Share of U.S. Transnational Corporation Manufacturing Trade by Country ${ }^{\mathrm{a}}$

Percent

\begin{tabular}{lrr}
\hline & 1977 & 1990 \\
\hline Developed countries & & \\
Ireland & 32.6 & 47.7 \\
Canada & 51.2 & 41.9 \\
United Kingdom & 19.4 & 23.3 \\
Netherlands & 16.9 & 18.2 \\
Australia & $\ldots$ & 17.4 \\
Belgium & 21.7 & 15.1 \\
Germany & 12.4 & 14.1 \\
France & 13.2 & 11.7 \\
Italy & 6.8 & 8.4 \\
Denmark & $\ldots$ & 3.8 \\
Sweden & 3.4 & 3.5 \\
Japan & $\ldots .1$ & 3.1 \\
Switzerland & 1.1 & 2.4 \\
Norway & 5.6 & 2.3 \\
New Zealand & 2.4 & 2.2 \\
Austria & 4.0 & $\ldots$ \\
Bahamas & 0.02 & $\ldots$ \\
Developing countries & & \\
Singapore & $\ldots .4$ & 42.4 \\
Mexico & 13.9 & 30.0 \\
Malaysia & 29.1 & 28.0 \\
Brazil & 22.5 & 25.1 \\
Thailand & 10.6 & 16.9 \\
Hong Kong & 10.7 & 16.4 \\
Philippines & 10.8 & 11.7 \\
Spain & 11.3 \\
Argentina & 7.4 \\
Israel & 5.5 \\
& & \\
& & \\
& & \\
& & \\
(continued)
\end{tabular}

on an increasingly sophisticated division of labor and specialization, and thus on increased intra-industry trade flows. Trade is negatively related to distance, with a coefficient of about negative one in the regressions that include the entire sample, meaning that a doubling of distance approximately halves the volume of trade. A dummy variable for adjacency (with Canada and Mexico), as used in other gravity equations in the literature, was not statistically significant. A dummy variable for former membership in the socialist trading bloc has a highly significant neg- 


\begin{tabular}{lcc}
\hline & 1977 & 1990 \\
\hline Taiwan & 10.1 & 5.4 \\
Chile & 2.4 & 5.2 \\
Colombia & 11.5 & 4.5 \\
Costa Rica & $\ldots$ & 3.9 \\
Barbados & $\ldots$ & 3.6 \\
Peru & 3.2 & 3.5 \\
Guatemala & $\ldots$. & 3.0 \\
Dominican Republic & $\ldots$. & 2.5 \\
Korea & 4.5 & 2.2 \\
Greece & $\ldots$. & 1.4 \\
Egypt & 0.0 & 1.3 \\
Indonesia & 4.0 & 0.7 \\
Turkey & $\ldots$. & 0.7 \\
India & 0.6 & 0.4 \\
China & $\ldots$. & 0.04 \\
Portugal & 13.6 & $\ldots$ \\
Panama & 4.2 & $\ldots$ \\
\hline
\end{tabular}

Source: Authors' calculations using U.S. Bureau of Economic Analysis (1981, 1991a).

a. Transnational corporation trade by country is the sum of manufacturing exports and imports between the United States and majority-owned nonbank affiliates of nonbank U.S. parents divided by the sum of U.S. manufacturing exports to the country and U.S. imports from the country. For 1990, TNC exports were imputed for South Africa, and imports were imputed for India, Peru, Switzerland, Denmark, and Norway, based on trade for all nonbank foreign affiliates. For 1977, exports were imputed for Norway, and imports were imputed for Indonesia, Thailand, Colombia, Norway, and Ireland. Several countries have listings for 1990 but not 1977 in official sources. They include Costa Rica, Barbados, Guatemala, the Dominican Republic, and China. In addition, the following countries had data suppressed in one of the two years. Each country is listed with the lower bound, when possible, of the TNC trade measure, followed by the nonsuppressed variable on which it is based.

\begin{tabular}{|c|c|c|c|c|c|}
\hline \multicolumn{3}{|c|}{ Suppressed in 1990} & \multicolumn{3}{|c|}{ Suppressed in 1977} \\
\hline Austria & 4.9 & (exports) & Australia & 17.7 & (exports) \\
\hline Bahamas & 0.1 & (exports) & $\begin{array}{l}\text { Denmark } \\
\text { Switzerland }\end{array}$ & 6.3 & (exports) \\
\hline Panama & 2.1 & (exports) & Greece & 4.9 & (exports) \\
\hline \multirow[t]{3}{*}{ Portugal } & 1.2 & (imports) & Israel & 1.9 & (exports) \\
\hline & & & Singapore & 9.2 & (exports) \\
\hline & & & Turkey & $\ldots$ & \\
\hline
\end{tabular}

ative effect on trade in both 1978 and 1990, as we would expect. This is relevant for later analysis, when we ask how trade might develop between the United States and these economies in transition.

The TNC variables are statistically significant in 1990, with the expected positive sign: more TNC-based trade leads to a larger overall trade volume. They are not significant, however, in 1978. Since the coefficient on TNC is about 3.4, an increase of 10 percentage points of total trade within TNCs is estimated to increase the volume of exports and imports by about 40 percent $[\exp (3.4 \times 0.10)-1=0.40]$. As the developing countries open their markets to foreign direct investment, as 
Table 18. Gravity Equations ${ }^{a}$

\begin{tabular}{|c|c|c|c|c|c|c|c|c|c|c|c|c|}
\hline \multirow{3}{*}{$\begin{array}{l}\text { Independent } \\
\text { variable }\end{array}$} & \multicolumn{6}{|c|}{1990} & \multicolumn{6}{|c|}{1978} \\
\hline & \multicolumn{3}{|c|}{ Exports } & \multicolumn{3}{|c|}{ Imports } & \multicolumn{3}{|c|}{ Exports } & \multicolumn{3}{|c|}{ Imports } \\
\hline & $18-1$ & $18-2$ & $18-3$ & $18-4$ & $18-5$ & $18-6$ & $18-7$ & $18-8$ & $18-9$ & $18-10$ & $18-11$ & $18-12$ \\
\hline GDP per capita ${ }^{b}$ & $\begin{array}{l}1.61^{* *} \\
(15.10)\end{array}$ & $\begin{array}{l}1.03 * * \\
(7.14)\end{array}$ & $\begin{array}{l}1.50^{* *} \\
(12.84)\end{array}$ & $\begin{array}{l}2.03^{* *} \\
(13.65)\end{array}$ & $\begin{array}{l}1.21 * * \\
(5.52)\end{array}$ & $\begin{array}{l}1.91^{* *} \\
(11.64)\end{array}$ & $\begin{array}{l}1.43^{* *} \\
(13.92)\end{array}$ & $\begin{array}{l}0.78^{* *} \\
(4.44)\end{array}$ & $\begin{array}{l}1.44^{* *} \\
(12.94)\end{array}$ & $\begin{array}{l}2.52^{* *} \\
(11.34)\end{array}$ & $\begin{array}{l}1.48^{* *} \\
(5.03)\end{array}$ & $\begin{array}{c}2.52 * * \\
(10.51)\end{array}$ \\
\hline Population $^{b}$ & $\begin{array}{c}0.89^{* *} \\
(14.06)\end{array}$ & $\begin{array}{l}0.61 * * \\
(9.18)\end{array}$ & $\begin{array}{l}0.85^{* *} \\
(13.14)\end{array}$ & $\begin{array}{l}1.12^{* * *} \\
(12.75)\end{array}$ & $\begin{array}{l}0.77 * * \\
(7.72)\end{array}$ & $\begin{array}{l}1.08^{* *} \\
(11.89)\end{array}$ & $\begin{array}{l}0.91^{* *} \\
(15.59)\end{array}$ & $\begin{array}{l}0.60 * * \\
(7.16)\end{array}$ & $\begin{array}{l}0.91^{* *} \\
(14.42)\end{array}$ & $\begin{array}{l}1.16^{* *} \\
(9.50)\end{array}$ & $\begin{array}{l}0.62 * * \\
(4.41)\end{array}$ & $\begin{array}{c}1.16 \\
(8.76)\end{array}$ \\
\hline Distance $^{c}$ & $\begin{array}{l}-1.38^{* *} \\
(-6.09)\end{array}$ & $\begin{array}{l}-0.28^{* *} \\
(-1.60)\end{array}$ & $\begin{array}{l}-1.28^{* *} \\
(-5.69)\end{array}$ & $\begin{array}{l}-1.01^{* *} \\
(-3.24)\end{array}$ & $\begin{array}{l}-0.11^{* *} \\
(-0.42)\end{array}$ & $\begin{array}{l}-0.92 * * \\
(-2.92)\end{array}$ & $\begin{array}{c}-1.22^{*} \\
(-6.24)\end{array}$ & $\begin{array}{l}-0.54^{*} \\
(-2.40)\end{array}$ & $\begin{array}{l}-1.23^{* *} \\
(-6.02)\end{array}$ & $\begin{array}{l}-0.98^{*} \\
(-2.33)\end{array}$ & $\begin{array}{c}-0.08 \\
(-0.22)\end{array}$ & $\begin{array}{l}-0.97^{*} \\
(-2.22)\end{array}$ \\
\hline $\begin{array}{l}\text { Former socialist } \\
\text { economies }\end{array}$ & $\begin{array}{l}-2.36^{* *} \\
(-4.61)\end{array}$ & $\begin{array}{l}-2.34^{* *} \\
(-8.10)\end{array}$ & $\begin{array}{l}-2.08^{* *} \\
(-4.03)\end{array}$ & $\begin{array}{l}-2.21^{* *} \\
(-3.13)\end{array}$ & $\begin{array}{l}-2.19^{* *} \\
(-5.01)\end{array}$ & $\begin{array}{l}-1.93 * * \\
(-2.68)\end{array}$ & $\begin{array}{l}-1.94 * * \\
(-3.98)\end{array}$ & $\begin{array}{l}-1.77 * * \\
(-5.09)\end{array}$ & $\begin{array}{l}-1.95^{* *} \\
(-3.87)\end{array}$ & $\begin{array}{c}-1.82 \\
(-1.74)\end{array}$ & $\begin{array}{l}-1.71 * * \\
(-2.96)\end{array}$ & $\begin{array}{c}-1.82 \\
(-1.67)\end{array}$ \\
\hline $\mathrm{TNC}^{\mathrm{d}}$ & $\ldots$ & $\begin{array}{l}3.45^{* *} \\
(3.93)\end{array}$ & $\begin{array}{r}3.26^{*} \\
(2.26)\end{array}$ & $\ldots$ & $\begin{array}{l}3.61^{* *} \\
(2.71)\end{array}$ & $\begin{array}{c}3.32 \\
(1.65)\end{array}$ & $\ldots$ & $\begin{array}{l}1.81 \\
(1.445)\end{array}$ & $\begin{array}{l}-0.20 \\
(-0.13)\end{array}$ & $\ldots$ & $\begin{array}{c}1.98 \\
(0.95)\end{array}$ & $\begin{array}{c}0.08 \\
(0.024)\end{array}$ \\
\hline Constant & $\begin{array}{c}-3.61 \\
(-1.57)\end{array}$ & $\begin{array}{l}-5.04^{*} \\
(-2.41)\end{array}$ & $\begin{array}{c}-3.25 \\
(-1.43)\end{array}$ & $\begin{array}{l}-12.60^{* *} \\
(-3.94)\end{array}$ & $\begin{array}{l}-9.71^{* *} \\
(-3.06)\end{array}$ & $\begin{array}{l}-12.22^{* *} \\
(-3.84)\end{array}$ & $\begin{array}{c}-4.03 \\
(-1.90)\end{array}$ & $\begin{array}{c}-1.23 \\
(-0.435)\end{array}$ & $\begin{array}{c}-4.03 \\
(-1.89)\end{array}$ & $\begin{array}{l}-18.15^{* *} \\
(-4.02)\end{array}$ & $\begin{array}{l}-11.36^{*} \\
(-2.41)\end{array}$ & $\begin{array}{l}-18.15 \\
(-4.00)\end{array}$ \\
\hline $\begin{array}{l}\text { Addendum } \\
\overline{\mathrm{R}}^{2}\end{array}$ & 0.81 & 0.84 & 0.82 & 0.77 & 0.74 & 0.77 & 0.82 & 0.75 & 0.82 & 0.68 & 0.57 & 0.68 \\
\hline $\begin{array}{l}\text { Number of } \\
\text { observations }\end{array}$ & 120 & 45 & 120 & 119 & 45 & 119 & 118 & 37 & 118 & 119 & 37 & 119 \\
\hline
\end{tabular}

Source: Authors' regressions based on U.S. Bureau of Economic Analysis (1981, 1991a); Penn World Tables, Mark 5.5; and Fitzpatrick and Modlin (1986).

a. Equations 18-1 and 18-7 are the basic export equations for 1990 and 1978. Equations 18-4 and 18-10 are the basic import equations for 1990 and 1978. Equations 18-2 and 18-8 are the basic export equations plus a variable for TNC trade. Equations 18-5 and 18-11 are the basic import equations plus a variable for TNC trade. Equations 18-3 and 18-9 are the basic export equations with the variable for TNC trade set equal to zero when it is otherwise missing. Equations 18-6 and 18-12 are the basic import equations with the variable for TNC trade set equal to zero when it is otherwise missing. All variables are in logs, except the former socialist dummy and the TNC variable, which is the ratio of total U.S. exports and imports of majority-owned nonbank affiliates in a country to total U.S. exports and imports of the country. The former socialist dummy is one if the country was a member of the Council for Mutual Economic Assistance, zero otherwise.

One asterisk (*) denotes significance at the 5 percent level. Two asterisks $\left(^{* *}\right)$ denotes significance at the 1 percent level. Numbers in parentheses are $t$-statistics.

b. GDP and population variables in the 1990 equation are for 1989.

c. Distance is statute miles from the capital city to Chicago.

d. The TNC variable in the 1978 equation is for 1977. 
has Mexico, one should expect their volume of trade with the United States, both exports and imports, to increase as well.

One concern highlighted in the NAFTA debate is that Mexico, and by extension other low-wage countries, will become "export platforms" to the United States. The assertion is that large flows of foreign direct investment will create production facilities based on low-wage labor for reexport to the United States. The gravity equations suggest some truth to this concern, though the increased trade volumes seem to occur for both exports and imports. The United States will likely absorb more non-skill-intensive production and export more skill-intensive production as a result of the increased two-way trade.

To investigate this hypothesis, we estimate a cross-country regression of U.S. net trade patterns for different skill categories of goods. For each skill decile $i$, we measure the U.S. net trade with each country $j$ as

$$
n_{i j}=\left(X_{i j}-M_{i j}\right) /\left(X_{i j}+M_{i j}\right) .
$$

Then, within each skill decile, we estimate the following cross-country regression:

$$
n_{i j}=\beta_{0}+\beta_{1} \log \left(w_{j} / w_{U S}\right)+\beta_{2} T N C_{j} .
$$

For low-skill deciles, we expect $\beta_{1}$ to be positive: the U.S. net trade position should be higher for high-wage partner countries. For high-skill deciles, we expect $\beta_{1}$ to be negative. In that case, the U.S. net trade position should be higher with low-wage countries than with high-wage countries.

We allow the TNC variable to have different coefficients for developing and developed countries. That is, the variable is estimated as $\beta_{2} L D C_{j} T N C_{j}+\beta_{3}\left(1-L D C_{j}\right) T N C_{j}$, where $L D C_{j}$ takes a value of one if the country is a developing economy and a value of zero if the country is a developed economy. For developing countries, we test the hypothesis that the U.S. net trade deficit is more negative in the presence of greater TNC-based trade. That is, we expect $\beta_{2}$ to be negative, at least for the less skill-intensive goods. For developed economies, TNC-based trade increases the total volume of trade, but there is no particular reason to expect that it would lead to larger or smaller net trade positions, so that we expect $\beta_{3}$ to be close to zero.

The results of the estimation are shown in table 19. As expected, $\beta_{1}$ is negative for skill-intensive production (all deciles 1-8) and positive for non-skill-intensive production (deciles 9-10). The TNC variable is nega- 
Table 19. Regressions of Net Exports by Skill Decile on Wages and TNC Trade, 1990a

\begin{tabular}{|c|c|c|c|c|c|c|c|c|c|c|}
\hline \multirow{2}{*}{$\begin{array}{l}\text { Independent } \\
\text { variable }^{\mathrm{b}}\end{array}$} & \multicolumn{10}{|c|}{ Skill decile } \\
\hline & 1 & 2 & 3 & 4 & 5 & 6 & 7 & 8 & 9 & 10 \\
\hline Wage ratio & $\begin{array}{l}-0.62 * * \\
(-5.38)\end{array}$ & $\begin{array}{l}-0.54 * * \\
(-5.31)\end{array}$ & $\begin{array}{l}-0.65^{* *} \\
(-5.09)\end{array}$ & $\begin{array}{c}-0.42^{*} \\
(-2.24)\end{array}$ & $\begin{array}{c}-0.25 \\
(-1.28)\end{array}$ & $\begin{array}{l}-0.93^{* *} \\
(-4.84)\end{array}$ & $\begin{array}{c}-0.18 \\
(-0.85)\end{array}$ & $\begin{array}{c}-0.34 \\
(-1.62)\end{array}$ & $\begin{array}{c}0.21 \\
(1.14)\end{array}$ & $\begin{array}{c}0.25 \\
(1.15)\end{array}$ \\
\hline $\begin{array}{l}\text { TNCs (develop- } \\
\text { ing countries) }\end{array}$ & $\begin{array}{l}-3.12 * * \\
(-5.62)\end{array}$ & $\begin{array}{c}-0.21 \\
(-0.43)\end{array}$ & $\begin{array}{l}-1.62 * * \\
(-2.61)\end{array}$ & $\begin{array}{l}-2.70 * * \\
(-2.98)\end{array}$ & $\begin{array}{c}-0.39 \\
(-0.41)\end{array}$ & $\begin{array}{c}-2.04 * \\
(-2.22)\end{array}$ & $\begin{array}{c}-1.02 \\
(-0.99)\end{array}$ & $\begin{array}{c}-1.30 \\
(-1.29)\end{array}$ & $\begin{array}{c}-1.72 \\
(-1.93)\end{array}$ & $\begin{array}{l}-2.36^{*} \\
(-2.28)\end{array}$ \\
\hline $\begin{array}{l}\text { TNCs (devel- } \\
\text { oped countries) }\end{array}$ & $\begin{array}{c}0.16 \\
(0.26)\end{array}$ & $\begin{array}{c}-0.14 \\
(-0.26)\end{array}$ & $\begin{array}{c}0.41 \\
(0.62)\end{array}$ & $\begin{array}{c}0.26 \\
(0.27)\end{array}$ & $\begin{array}{c}0.27 \\
(0.26)\end{array}$ & $\begin{array}{c}0.78 \\
(0.80)\end{array}$ & $\begin{array}{c}0.72 \\
(0.66)\end{array}$ & $\begin{array}{l}-1.04 \\
(-0.96)\end{array}$ & $\begin{array}{c}0.92 \\
(0.97)\end{array}$ & $\begin{array}{c}0.23 \\
(0.21)\end{array}$ \\
\hline Constant & $\begin{array}{c}0.85^{* *} \\
(17.38)\end{array}$ & $\begin{array}{c}0.85^{* *} \\
(19.45)\end{array}$ & $\begin{array}{c}0.70^{* *} \\
(12.75)\end{array}$ & $\begin{array}{l}0.44 * * \\
(5.48)\end{array}$ & $\begin{array}{l}0.23^{* *} \\
(2.79)\end{array}$ & $\begin{array}{l}0.51^{* *} \\
(6.15)\end{array}$ & $\begin{array}{c}-0.01 \\
(-0.97)\end{array}$ & $\begin{array}{c}0.40^{* *} \\
(4.47)\end{array}$ & $\begin{array}{l}-0.40^{* *} \\
(-5.09)\end{array}$ & $\begin{array}{c}-0.12 \\
(-1.32)\end{array}$ \\
\hline $\begin{array}{l}\text { Addendum } \\
\overline{\mathrm{R}}^{2}\end{array}$ & 0.39 & 0.27 & 0.26 & 0.16 & -0.01 & 0.23 & -0.01 & 0.05 & 0.05 & 0.05 \\
\hline $\begin{array}{l}\text { Number of } \\
\text { observations }\end{array}$ & 102 & 102 & 102 & 101 & 101 & 100 & 100 & 101 & 102 & 100 \\
\hline
\end{tabular}

Source: Authors' regressions using data from International Labour Office (1993); U.S. Bureau of the Census; U.S. Bureau of Economic Analysis (1991a).

a. Dependent variable is decile net exports (exports minus imports) divided by total decile trade (exports plus imports). One asterisk $\left({ }^{*}\right)$ denotes significance at the 5 percent level. Two asterisks $(* *)$ denote significance at the 1 percent level. Numbers in parentheses are $t$-statistics.

b. The wage ratio is the local monthly wage divided by the U.S. monthly wage for 1990. TNC variables (TNC exports plus imports over country exports plus imports) are interacted with dummies for developing countries and developed countries to create different coefficients. 
tive for all deciles for the developing countries: higher TNC-based trade is associated with larger U.S. net trade deficits with developing countries. The variable is statistically significant in half of the cases. In the case of developed economies, the TNC variable is sometimes positive and sometimes negative, but is always small and statistically insignificant. These results suggest that foreign-based production in low-wage countries is used as an export platform for reexport to the United States. It is also consistent with another interpretation: that when U.S. firms engage in foreign-based production in developing countries, they supply the foreign market more through production at the foreign base than through exports from the United States. The former interpretation is most likely for less skill-intensive goods and the latter for more skill-intensive goods. To go further requires data on the kinds of goods involved in TNC-based trade with each country. We have not yet attempted to collect such data.

\section{Future Prospects for Trade with Developing Countries}

We have seen that intense import competition from developing countries has led to substantial job losses in low-skill manufacturing. Moreover, the trends that have led to increased integration between the United States and the developing countries are almost surely intensifying, not slackening. Among these trends, one can mention substantial and continuing trade liberalization in the developing world; substantial increases in foreign direct investment and portfolio flows; international agreements including NAFTA and the Uruguay Round of the GATT; continuing reductions in transport and communication costs; and rapid GDP growth and output potential of outward-oriented low-wage countries. $^{39}$

In general, two basic forces are at work. On the one hand, there will be an increase in trade competition coming from low-wage countries as a result of trade and investment liberalization. One can point to China, India, Mexico, and the former socialist economies as key regions from which the United States can expect an increase in low-wage competition. On the other hand, as economic development proceeds, the lowwage countries of today will become the middle-wage countries of the

39. See General Agreement on Tariffs and Trade (1993) and Hickok (1993) for trade liberalization trends and United Nations $(1992,1993)$ for investment trends. 
future (just as occurred with Europe and Japan between the 1960s and 1980s). This latter trend could, in principle, ease some of the pressures on low-skill employment. A cross-country equation shows that in 1990, each 1 percent narrowing of the gap income (per capita GDP) with the United States is associated with a 1.42 percent narrowing of the wage gap with the United States. ${ }^{40}$

We now briefly consider some of the key regions and their future implications for U.S. trade. We start with China, where total trade in manufactured goods (exports plus imports) with the United States has grown from $\$ 0.5$ billion in 1978 ( 0.2 percent of U.S. manufacturing trade) to $\$ 17.5$ billion in 1990 ( 2.4 percent of U.S. manufacturing trade), and the U.S. trade balance with China shifted from a tiny surplus of $\$ 50$ million in 1978 to deficits of $\$ 10$ billion in 1990 and $\$ 18$ billion in 1992. China's trade boom in the 1980s is surely one of the most remarkable in history, built on low wages, enormous internal savings, foreign investment from Greater China (Taiwan and Hong Kong), and management expertise and service sector support from Hong Kong.

The structure of China's trade with the United States fits the general HOS pattern, as shown in table 20, with a heavy concentration of U.S. imports from China in low-skill sectors (41 percent of imports come from deciles 9 and 10) and a heavy concentration of U.S. exports to China in high-skill sectors (78 percent of U.S. exports are in deciles 1-3). China also has substantial exports in two relatively high-skill sectors: toys and sporting goods (within decile 5) and radio and TV receiving equipment (within decile 4). We suspect China is exporting in niches in these sectors that are considerably less skill intensive than the sectors as a whole. The Chinese radio and TV industry is heavily oriented toward assembly operations, as is the toy industry (such as the production of stuffed animals).

The rise in Chinese exports is slightly less dramatic than it looks, since China has to some extent replaced similar exports from Taiwan and Hong Kong, as those economies have moved the bulk of their own

40. The estimated equation is

$$
\log \left(w_{i} / w_{U S}\right)=\beta_{0}+\beta_{1} \log \left(Y_{i} / Y_{U S}\right),
$$

where $w_{i}$ is the average wage of country $i$, and $Y_{i}$ is the Summers-Heston (Penn-World tables) per capita income. The regression is estimated for a cross-section of 49 countries. The estimated coefficient $\beta_{1}$ is 1.42 with a standard error of 0.15 . $\beta_{0}$ is estimated as 0.26 with a standard error of 0.23 . 
Table 20. Composition of U.S. Trade with China, 1990

Percent, except as noted

\begin{tabular}{ccccc}
\hline & $\begin{array}{c}\text { Share of } \\
\text { imports to } \\
\text { United States }\end{array}$ & $\begin{array}{c}\text { a } \\
\text { Share of } \\
\text { exports from } \\
\text { United States }^{\mathrm{a}}\end{array}$ & $\begin{array}{c}\text { Net imports, } \\
\text { percent of } \\
\text { decile value- } \\
\text { added }^{\mathrm{b}}\end{array}$ & $\begin{array}{c}\text { Net imports, } \\
\text { percent of } \\
\text { manufacturing } \\
\text { value-added }^{\mathrm{b}}\end{array}$ \\
\hline 1 & 4.8 & 7.7 & 0.1 & 0.0 \\
2 & 2.6 & 48.8 & -0.8 & -0.1 \\
3 & 3.9 & 21.3 & -0.1 & -0.0 \\
4 & 11.5 & 4.3 & 1.5 & 0.1 \\
5 & 18.9 & 6.3 & 1.8 & 0.2 \\
6 & 8.2 & 1.3 & 1.1 & 0.1 \\
7 & 4.1 & 2.8 & 0.7 & 0.0 \\
8 & 5.2 & 1.8 & 0.4 & 0.1 \\
9 & 17.2 & 0.4 & 4.1 & 0.2 \\
10 & 23.5 & 5.2 & 6.7 & 0.2 \\
Addendum & & & & \\
Dollar value & & & & \\
of trade & & & & \\
(in millions) & $13,730.11$ & $3,830.84$ & & \\
\hline
\end{tabular}

Source: Authors' calculations using data from the U.S. Bureau of the Census (1992) as described in appendix A. a. Share data are the imports (exports) for the decile divided by total imports (exports) between the U.S. and China.

b. Net imports are manufacturing imports from China to the United States minus manufacturing exports from the United States to China.

labor-intensive export industries, such as footwear and textiles, to China. For example, after growing by $\$ 1.3$ billion during $1978-85$, Taiwan's exports of nonrubber footwear to the United States fell by $\$ 1.1$ billion during 1985-92, while China's exports of footwear rose by $\$ 1.9$ billion during the same period. In recent years, Hong Kong has become substantially a service economy, while Taiwan's manufacturing has moved into much higher skill categories. This replacement effect is probably at an end, however, since most low-skill production has now been shifted to the mainland.

We can expect a continued rapid rise of trade with China for two reasons: continued rapid growth of Chinese GDP and very rapid increases in foreign direct investment in China, which promise a rise of TNCbased trade. It is estimated that actual foreign direct investment increased to about $\$ 25$ billion in 1993, while new investment commitments for future years exceeded $\$ 120$ billion! To get a sense of how fast U.S.Chinese trade may grow in the future, assume (conservatively) that China grows at 6 percent a year in per capita terms and 1 percent a year 
in population; that the share of TNC-based trade with the United States rises at 0.5 percentage point a year; and that the United States grows at 2 percent a year in per capita terms and 0.6 percent a year in population..$^{41}$ In that case, the gravity equation predicts that the volume of U.S. trade with China will grow at approximately 16.1 percent a year. ${ }^{42}$ Moreover, China will remain a low-wage country for the foreseeable future, even with this rapid growth. In 1990, Chinese average wages were an estimated 1.9 percent of U.S. wages. Using an estimated elasticity of the wage gap with respect to the GDP gap of 1.4, after 10 more years of rapid Chinese growth, the Chinese wage will still be only 3.2 percent of the U.S. wage.

India has lagged behind China in opening its economy by nearly a decade. Nonetheless, on the basis of India's reforms since 1991, there is already a significant expansion of GDP growth, a jump in foreign direct investment, and an increase in trade. U.S. investment in India rose from $\$ 53$ million in 1988 to more than $\$ 240$ million in 1993 . Total trade increased from $\$ 5.4$ billion in 1991 to $\$ 7.2$ billion in 1993. Assuming rapid growth in India in the next decade, as well as substantial liberalization of foreign direct investment, one could expect a sizable increase in trade with the United States, with India's exports surely concentrated among the less skill-intensive sectors. Suppose, for example, that India's real per capita GDP grows by 6 percent a year, population grows by 1.8 percent a year, and the share of TNC-based trade increases by 0.5 percentage point a year. The gravity equation predicts that the volume of trade would grow by 16.8 percent a year. Moreover, there may be a period of "catching-up" in the level of trade with the United States, following the general liberalization of the Indian trading system, though the gravity equation did not suggest that India was a significant negative outlier in trade levels as of $1990 .{ }^{43}$

41. The predicted population growth rates are taken from the forecasts for population growth during 1990-2010 in The Economist (1990).

42. In applying the gravity equations, we take a middle range of the estimated coefficients, using an elasticity of trade with respect to population of 0.9 , an elasticity of trade with respect to per capita income of 1.6, and a coefficient on TNC of 3.5. We also assume that the coefficients on income and population apply for U.S. growth as well as partner country growth.

43. When we estimated the gravity equation with a dummy variable for India, the variable was statistically insignificant, suggesting that Indian trade was not unusually small given per capita GNP, distance, and the absence of TNC-based trade. 
A third area in which U.S. trade might expand dramatically is with the former socialist economies. In the gravity equation, the dummy variable for these countries has an estimated coefficient of about -2.2 , suggesting that the volume of trade is currently around one-ninth of what would be expected on the basis of income, population, and distance $[\exp (2.2)=9.03] .{ }^{44}$ If we assume that market reforms will eliminate this discrepancy, trade volumes could rise ninefold in the coming years even without any changes in income levels or foreign direct investment. Of course, since these countries are also likely to grow and receive foreign direct investment, the increase in trade volumes could be even larger. Since 1990, trade between the United States and the countries in transition has been $\$ 5.2$ billion, or 0.7 percent of total U.S. trade; other things equal, a ninefold increase would raise the share of the former socialist countries to about 6 percent of U.S. trade. Most of these countries currently have wages of 5-10 percent of U.S. wages, and they are likely to remain below 25 percent of U.S. wages for the coming decade.

A fourth area where we might expect significant increases of trade is with Mexico. As with India, the gravity equation does not suggest that trade with Mexico is unusually low, controlling for other structural features. Nonetheless, we would still expect trade to increase on the basis of overall Mexican growth and a significant increase in the share of U.S.Mexican trade within TNCs as a result of NAFTA. Suppose that the proportion of TNC-based trade between the United States and Mexico rises from 30 percent in 1990 to 42 percent, which was the proportion with Canada in 1990. Since the TNC variable has an estimated coefficient of around 3.4 in the gravity equation, we would predict an increase in U.S.Mexican trade volume equal to $\exp [(0.42-0.30) 3.4]-1=0.50$, or 50 percent on this account alone.

To go further than these observations requires a dynamic structural trade model, which is beyond the scope of the present paper. Nonetheless, even these cursory observations suggest the likelihood of considerable structural change ahead in U.S. trade patterns. The pace of internationalization is likely to be as intensive in the next decade as it has been during the past 15 years.

One important area for future research is the likelihood of major internationalization of the service sector, since this would have further im-

44. The countries covered by this variable in the gravity equation include Bulgaria, Czechoslovakia, Hungary, Poland, Romania, the Soviet Union, and Yugoslavia. 
Table 21. Changing Structure of U.S. Trade, 1978 and 1990

Percent of GDP

\begin{tabular}{lrr}
\hline \multicolumn{1}{c}{ Trade category } & 1978 & 1990 \\
\hline Exports & 9.90 & 11.77 \\
Merchandise & 6.36 & 7.02 \\
Manufacturing & 4.82 & 5.78 \\
Services & 1.59 & 2.40 \\
Transfers under U.S. military agency & & \\
sales contracts & 0.35 & 0.18 \\
Travel & 0.32 & 0.73 \\
Passenger fares & 0.07 & 0.22 \\
Other transportation & 0.36 & 0.40 \\
Royalties and license fees & 0.26 & 0.28 \\
Other private services & 0.19 & 0.58 \\
U.S. government miscellaneous services & 0.03 & 0.12 \\
Income receipts on U.S. assets abroad & 1.99 & 2.34 \\
Direct investment receipts & 1.19 & 0.98 \\
Other private receipts & 0.72 & 1.18 \\
U.S. government receipts & 0.08 & 0.18 \\
Imports & 10.27 & 13.03 \\
Merchandise & 7.96 & 8.97 \\
Manufacturing & 5.38 & 7.35 \\
Services & 1.42 & 1.93 \\
Direct defense expenditures & 0.32 & 0.31 \\
Travel & 0.38 & 0.70 \\
Passenger fares & 0.13 & 0.16 \\
Other transportation & 0.38 & 0.42 \\
Royalties and license fees & 0.03 & 0.04 \\
Other private services & 0.11 & 0.25 \\
U.S. government miscellaneous services & 0.07 & 0.04 \\
Income payments on foreign assets & & \\
in the U.S. & 0.98 & 0.13 \\
Direct investment payments & 0.18 & 1.42 \\
Other private payments & 0.41 & 0.68 \\
U.S. government payments & 0.39 & \\
\hline
\end{tabular}

Source: Authors' calculations based on Data Resources, Inc. data file; U.S. Bureau of the Census as described in appendix A; and Bach $(1980,1992)$.

portant implications for U.S. employment and wage patterns. We see in table 21 that services accounted for 20 percent of total U.S. exports of goods and services in 1990 and 15 percent of total imports. Most of this was tourism, passenger fares, and other transportation, though internationally traded business services ("other private services") reached $\$ 32$ billion in 1990, or more than 10 percent of manufacturing exports. Such services were only 3.9 percent of manufacturing exports in 1978. 
Trade in business services should grow rapidly in the future, because of the liberalization of services trade and increasing technological opportunities ${ }^{45}$ Internationally traded services include insurance, banking, engineering and construction, computer services, trading houses, accountancy, and advertising. It is usually assumed that the United States has a significant technological lead in producer services, but, as in manufacturing, there is likely to be an increase in both imports and exports of such services according to skill intensity. Already, a considerable amount of computer programming is subcontracted to low-wage countries (such as the case of Bangalore, India, which is now the center of significant amounts of data processing for transnational corporations). Growing trade in services could therefore add another importinduced widening in income distribution.

\section{Conclusions}

We have seen that U.S. trade with developing countries has grown markedly over the past 15 years and that such trade is broadly characterized by the patterns suggested by the Heckscher-Ohlin-Samuelson theory: the United States exports skill-intensive goods and imports less skill-intensive goods. The increased trade with East Asia, Brazil, and Mexico since 1978 has accentuated these patterns. As a result of increased internationalization, employment has declined sharply in lowskill sectors and has increased in high-skill sectors. In addition, the increased trade has contributed to falling relative prices of less skill-intensive goods and to the growing inequality of earnings between lowskilled and high-skilled workers, although the weight of the trade effect is uncertain.

The United States already responds to the pressures of HOS-type trade by offering modest levels of trade protection to low-skill sectors. Some of this protection will be diminished in the future as a result of the new Uruguay Round, as the Multi-Fiber Arrangement is phased out. In addition, increased trade with the developing countries is likely to exacerbate some of the observed trends. While increased trade with the developing countries is in the best overall interests of the U.S. economy and is vital for the future economic growth of the developing countries,

45. United Nations (1992, 1993) and Landesmann and Petit (1992). 
the dislocations to low-wage manufacturing workers deserve continued policy attention. The Clinton administration's call for programs of enhanced job training and assistance in job relocation would seem to represent important policy initiatives in the face of the continuing internationalization of the economy.

\section{APPENDIX A}

\section{Data}

This APpendix describes data sources. A full description of data sources and methods is available on request from the authors.

\section{Trade Data}

Our import data are imports for consumption at the customs value, usually the foreign port value. Our export data are domestic exports valued at free alongside ship value, the U.S. border price. All our trade data are compiled from official statistics of the U.S. Department of Commerce. Data from 1989 to 1992 come from data files on CD-ROM from the U.S. Bureau of the Census, entitled U.S. Imports History: Historical Survey, 1989-92, and U.S. Exports History: Historical Survey, 1989-92. Data from 1978 to 1985 come from the International Trade Administration's COMPRO mainframe computer system via the Census Bureau's Foreign Trade Division, Trade Data Services Branch.

We were not able to locate sources for machine-readable trade data by three-digit industry and partner country for years before 1978. The U.S. Bureau of the Census provides official printed reports showing trade by country and disaggregated commodity code at least as far back as 1964 , and trade by world area (approximately eight world areas) and disaggregated eight-digit SIC-based product codes as far back as $1965 . .^{46}$ However, time constraints prevented us from using them to generate trade by country and industry, which would have had to be done by hand. 
Trade data are originally collected by detailed commodity number and are not directly comparable with industry data, such as shipments, value-added, and employment, which are collected by SIC. Concordances exist, however, for different classification systems. Our COMPRO data was concorded by the Census Bureau. We concorded the 1989-92 data using concordances on the CD-ROMs.

The files that show correspondences between tariff codes and industry codes do not use the actual SIC codes but SIC-based codes. This means that a specific SIC code used for trade data may actually be a combination of several SIC codes, or only part of one SIC code. We were informed that there is no documentation showing specific SIC combinations used on the COMPRO system and the CD-ROMs but that, with trivial differences, the combinations were close to those listed in the Census Bureau publication U.S. Commodity Exports and Imports as Related to Output. To minimize error and maximize industry variability, we used the SIC-based codes at the three-digit level to link trade data to industry data. We further reapportioned and combined some of industries, giving us a total of 131 industries rather than the 143 that appear in the full SIC system.

All of our trade and industry data are reported on the basis of the 1972 revision to the SIC system. There was a minor revision in 1977 and a major revision in $1987 .{ }^{47}$ Our trade data for 1989-92 were initially classified by the 1987 SIC-based codes, and we translated them into the 1972 SIC codes using the bridge tables (tables 1.C-1 and 1.C-2) in the 1991 data file of the 1987 Census of Manufacturers from the U.S. Bureau of the Census. These tables show how variables such as value of shipments and employment for 1987-coded industries are derived from 1972-coded industries for the year 1987. We used the value of shipments ratios in apportioning imports and exports. We have also used some trade data for 1960 from the United Nations. ${ }^{48}$

\section{Industry Data}

Most of our industry data from 1958 to 1989 come from the NBER productivity data set, which itself extends the SRI-Penn Manufacturing

47. U.S. Office of Management and Budget $(1972,1987)$ and U.S. Office of Federal Statistical Policy and Standards (1978).

48. United Nations (1961). 
data set. ${ }^{49}$ Using the Annual Survey of Manufactures (for 1990 and $1991)^{50}$ and a 1993 data file from the U.S. Bureau of Economic Analysis (BEA) entitled SIC Manufacturing Establishment Shipments by FourDigit Industry, we extended the data set for the variables employment, production workers, payroll, production worker wages, value-added, value of shipments, and real output through 1991 . We redefined the industries of the 1990 and 1991 data according to the 1972 SIC codes the same way we redefined the trade data. In a few cases, we needed to impute data when they were suppressed for reasons of confidentiality. The full data set is now being extended by Eric J. Bartelsman at the Board of Governors of the Federal Reserve System. Our industry data before 1958 come from the Annual Survey of Manufactures 1959 and 1960. ${ }^{51}$

Capital and labor shares for 1978 were computed using total compensation figures from table 5 of the 1979 Annual Survey of Manufactures. ${ }^{52}$ We used the 1979 survey rather than the 1978 survey to capture revised figures.

The Annual Survey of Manufactures does not break down compensation by production workers and nonproduction workers. We divided total compensation between these two groups using the ratio of production wages to nonproduction wages. The share of production workers is production worker compensation divided by value-added; the share of nonproduction workers is nonproduction worker payroll divided by valueadded; and capital share is one minus total compensation divided by value-added.

The best source we could find for research and development was the U.S. Federal Trade Commission's annual, but now discontinued, $A n$ nual Line of Business Report, brought to our attention by F. M. Scherer at the Kennedy School, Harvard University. The last report was issued in 1985 for the year 1977. Our figures for research and development are the ratio of the cost of company $R \& D$ to total sales and transfers. The cost of company $R \& D$ is the research and development attributed to a specific line of business paid by company money. Total sales and transfers are the total sales and transfers attributed to that line of business.

Because of the classification system used in the Federal Trade Commission report, we had to further aggregate a few of our industries when

49. Abowd (1991), Gray (1987, 1989, and 1992); and Andrews and Zabala (1984).

50. U.S. Bureau of the Census (1992a, 1992b).

51. U.S. Bureau of the Census (1962).

52. U.S. Bureau of the Census (1981). 
using the R\&D data. When combined with the trade data, the full data set that included R\&D had 122 three-digit industries. We used this $122-$ industry data set only in analyses involving R\&D.

\section{Per Capita Income}

We divided countries into developing and developed countries according to the World Bank's 1979 classification..$^{53}$ We classified as "developing" countries all those listed as low- and middle-income countries by the World Bank. We classified as "developed" countries all those listed as industrialized. Our classifications created four anomalies. Spain and Portugal were classified as developing countries, while Czechoslovakia and the German Democratic Republic were classified as developed countries.

Countries that either did not exist in 1979 or were not listed in the 1979 report were classified according to their listing in $1993 .{ }^{54} \mathrm{~A}$ number of countries had trade data but did not appear in either World Bank list and were classified according to our best guess as to where they should fit.

\section{Wage Data}

The wage ratio used in the paper is the local monthly manufacturing wage divided by the U.S. monthly manufacturing wage. We computed these wages from data from the International Labour Office..$^{55}$ We left the monthly figures as they were.

We multiplied weekly figures by 4.33 and daily figures by 6 and then by 4.33 . For hourly figures, we referred to the "Hours of Work per Week in Manufacturing" table in various issues of the Year Books of Labour Statistics. ${ }^{56}$

We then converted country wage rates in local currency to U.S. currency using the IMF's "rf" exchange rate from International Financial Statistics. We enlarged the data set further by imputing wages using the

53. World Bank (1979).

54. World Bank (1993).

55. International Labour Office (1966, 1978, 1983, and 1993). Wage data for 1990, 1980, 1978, and 1970 are from table 17, "Wages in Manufacturing," in the 1978, 1983, and 1993 Year Book of Labour Statistics. For 1960, they are from table 19, "Wages in Manufacturing," in the 1966 year book.

56. See table 12 in the 1993, 1983, and 1978 year books, and table 13 in the 1966 year book. 
Penn-World Tables Mark 5.5 (also known as the Summers-Heston data). ${ }^{57} \mathrm{We}$ regressed the log of the local-to-U.S. wage ratio on the log of the ratio of local-to-U.S. real per capita GDPs (chain index; the RGDPCH variable) and then imputed missing wages using the regression results. ${ }^{58}$

\section{Data on Transnational Corporations}

Data for foreign direct investment come from U.S. Bureau of Economic Analysis. ${ }^{59}$ Although the years we focused on were 1978 and 1990, we had to use 1977 foreign direct investment data in lieu of 1978 because the annual series did not start until 1983. The data closest to 1978 were the figures appearing in a 1977 benchmark report. We used revised 1990 figures for 1990 trade. Our trade data are imports and exports between the United States and nonbank majority-owned affiliates of nonbank U.S. parents.

The listed countries had either a dollar total for exports and imports, an asterisk (signifying a dollar total of less than $\$ 500,000$ ), or a $D$ (meaning the data were suppressed to maintain confidentiality). We substituted $\$ 250,000$ whenever an asterisk appeared. We treated a $D$ as missing data, although in some analyses (noted in the text) we substituted a zero whenever a $D$ appeared or when the country was not listed in the data.

In several cases, we imputed exports or imports when the country had data for one type of TNC variable but not the one we used.

\section{Data for Gravity Equations}

In addition to the data described in other sections of this appendix, the gravity equations included country populations and air distances to Chicago. Population figures are from Penn-World Tables Mark 5.5. Distances are straight-line air distance in statute miles from the country capital to Chicago. ${ }^{60}$ In a few cases, we did not use the current capital city.

57. The Penn-World tables are described in Summers and Heston (1991).

58. Chinese wages come from the State Statistical Bureau of the People's Republic of China (1992, table T4.32). We used the annual wage for state-owned units and divided by 12 .

59. U.S. Bureau of Economic Analysis (1981, 1991a).

60. Fitzpatrick and Modlin (1986). 


\section{Input-Output Tables}

Our 1987 input-output matrix is taken from the Survey of Current Business, April 1992, table 5. The actual table came from a data file published by the U.S. Bureau of Economic Analysis entitled 1987 Annual Input-Output Accounts.

The input-output tables are coded according to two-digit and six-digit codes from the Bureau of Economic Analysis. The 1982 benchmark accounts have a concordance between these codes and SIC codes, which we used to link the tables to our trade and manufacturing data, converting all our SIC-coded industries into BEA-coded industries. ${ }^{61}$ As a result of combinations previously made because of data limitations, we had to combine two industries so that our input-output data set consisted of 51 two-digit manufacturing industries, rather than the 52 listed in the table.

\section{U.S. International Transactions and GDP}

Except for manufacturing trade, all statistics on U.S. international transactions in table 19 are from work done by Christopher Bach. ${ }^{62}$ GDP figures for this table and throughout the paper are from Data Resources, Inc., which reports data from the U.S. National Income and Product Accounts.

\section{Levels of Protection}

Data on tariffs and quotas come from the International Trade Commission and one of its staff members, Joseph E. Flynn of the Office of Economics. ${ }^{63}$ Flynn provided data compiled from official statistics of the Department of Commerce on the customs value, the dutiable value, and the calculated duties collected for imports by four-digit SIC-based industry for various years. We transformed these data the same way we transformed all other trade data, aggregating by three-digit industry and converting to 1972 SIC codes.

61. U.S. Bureau of Economic Analysis (1991b).

62. For 1990, data are from Bach (1992, table 1, p. 75). For 1978, data are from Bach (1980, table 1, p. 54).

63. U.S. International Trade Commission (1993) and personal correspondence with Joseph E. Flynn. 
Our data on tariff equivalents of quotas in 1991 refer specifically to industries covered in 1991 by the Arrangement Regarding International Trade in Textiles, also known as the Multi-Fiber Arrangement (MFA), the Voluntary Restraint Agreements (VRAs) on machine tools and steel, and the Voluntary Export Restraint (VER) on automobiles. ${ }^{64}$

We could find no single source of tariff-equivalent measures for quotas and other barriers for the United States in 1978, and so followed the research of Gary Hufbauer, Diane Berliner, and Kimberly Ann Elliott to make educated best guesses about what these might be ${ }^{65}$ Specifically, we quantified orderly marketing agreements, the trigger price mechanism for steel, the Multi-Fiber Arrangement, and any other quotas that were in effect during or around 1978, using the line-item "induced increase" in the price of the imported product from the "Quantitative Profile" by Hufbauer, Berliner, and Elliott. Our tariff equivalents are actually the percentage price increase imputed by various studies to an imported product as a result of some type of extra trade barrier.

Hufbauer and others, in their case studies of industries, did not identify the industries by SIC code. We therefore attributed the tariff equivalents to our best guess as to the most applicable industry.

\section{International Prices}

Import price indexes by industry come from a data file from the $\mathrm{Bu}$ reau of Labor Statistics and are reported as quarterly changes. We thank Robert Lawrence and Matthew Slaughter for giving us these data, which they used in their 1993 study. We use the annual average of these quarterly changes in our analysis.

\section{Skill Data}

David R. Howell and Edward N. Wolff have developed skill indexes for different occupations and industries. ${ }^{66}$ We thank Howell of the New

64. Industries covered by the MFA and the machine tool VRA were identified in U.S. International Trade Commission (1993). We identified the industries covered by the steel VRA and the automobile VER through personal communication with the commission.

65. Hufbauer, Berliner, and Elliott (1986).

66. See Howell and Wolff (1991a, 1991b, 1991c, and 1992) and their data appendix. 
School for Social Research for sending us the data for 1960, 1970, and 1980 and Frederic Pryor of Swarthmore for alerting us to their existence.

The data have skill rankings on a variety of scales for 64 different industries, of which 36 are manufacturing. These are coded by the 1970 Census of Population industry classifications. ${ }^{67}$ The Census Bureau also shows how these codes are related to the 1967 version of the Standard Industrial Classification.

Since our data were based on the 1972 SIC revision, we use the bridge tables in the 1972 Census of Manufactures to make the two data sets consistent. ${ }^{68}$

\section{APPENDIX B}

\section{Skill Classification}

THERE IS NO single agreed-upon method of identifying workers as either skilled or unskilled. Following work by Berman, Bound, and Griliches, and by Lawrence and Slaughter, we identify nonproduction workers as skilled and production workers as unskilled. ${ }^{69}$ While objections may be raised to this approach (Leamer being an example), the breakdown is most natural to our data set, and we believe there are good reasons to classify industry skill levels based on the share of each kind of worker an industry employs. ${ }^{70}$

Skills may be based on education, training, or time on the job, and the literature dealing with worker skills often looks at education or the distinction between white-collar and blue-collar labor. The Annual Survey of Manufactures, the source of most of the industry data used in this paper, disaggregates workers into production workers and nonproduction workers.

Berman, Bound, and Griliches show a tight fit between the percentage of white-collar workers in manufacturing and the percentage of nonproduction workers in manufacturing for three different years. They

67. U.S. Bureau of the Census (1971).

68. U.S. Bureau of the Census (1976).

69. Berman, Bound, and Griliches (1994) and Lawrence and Slaughter (1993).

70. Leamer (1994). 
Table B1. Data on Wage Differentials from Research by Murphy and Welch and from the Annual Survey of Manufactures (ASM) ${ }^{\mathrm{a}}$

Ratio

\begin{tabular}{ccc}
\hline Year & $\begin{array}{c}\text { Murphy and } \\
\text { Welch data }^{\mathrm{b}}\end{array}$ & $\begin{array}{c}\text { ASM } \\
\text { data }^{\mathrm{c}}\end{array}$ \\
\hline 1964 & 1.43 & 1.52 \\
1969 & 1.44 & 1.58 \\
1974 & 1.41 & 1.55 \\
1979 & 1.37 & 1.53 \\
1984 & 1.44 & 1.57 \\
1989 & 1.58 & 1.65 \\
\hline
\end{tabular}

Source: Murphy and Welch (1992) and the Annual Survey of Manufactures (various years).

a. Regressing the ASM data on the Murphy and Welch data gave a coefficient of 0.60 with a $t$-statistic of 4.48 , significant at the 0.05 level, and an adjusted $\mathrm{R}^{2}$ of 0.79 .

b. The Murphy and Welch data show the ratio of hourly wages for college-educated workers at all experience levels divided by the hourly wages for high school-educated workers at all experience levels.

c. The ASM data show the ratio of annual per capita nonproduction worker payroll to annual per capita production worker wages.

also report a tight fit between educational attainment and the survey's categories of workers. ${ }^{71}$

This fit between the production and nonproduction categories and educational and occupational categories can be found in other data. Murphy and Welch show the ratio of hourly wages of college graduates to those of high school graduates for selected years and levels of work experience. ${ }^{72}$ The trend for workers aggregated by all levels of experience tracks the differential found in the Annual Survey of Manufactures between per capita nonproduction payroll and production wages, as shown in table B1. This relationship does not fit well, however, when the survey data are compared with differentials for different experience groups.

Data from research by Davis and Haltiwanger also support the use of the survey categories. ${ }^{73}$ They report the distribution of hours worked in manufacturing by educational category for seven different periods. We have regrouped their data into two educational categories and compare their numbers with the distribution of production and nonproduction workers in the Annual Survey of Manufactures data. The trends are very close, as shown in table B2.

While the standard data sets do not break down employment on the basis of specifically identified skills, Howell and Wolff have developed

71. Berman, Bound, and Griliches (1994, tables 1-2).

72. Murphy and Welch (1992, table 5, p. 300).

73. Davis and Haltiwanger (1991), especially appendix table 1. 
Table B2. Share of Hours Worked by Education Group and Share of Employment among Production and Nonproduction Workers

Percentage

\begin{tabular}{cccccc}
\hline & \multicolumn{2}{c}{ Share by education $^{\mathrm{a}}$} & & \multicolumn{2}{c}{ Share by worker group $^{\mathrm{b}}$} \\
\cline { 2 - 3 } \cline { 5 - 6 } Years & High school & College & & Production & Nonproduction \\
\hline $1967-69$ & 79.68 & 20.32 & & 75.26 & 24.74 \\
$1970-72$ & 79.16 & 20.84 & & 74.36 & 25.64 \\
$1973-75$ & 76.03 & 23.97 & & 74.46 & 25.54 \\
$1976-78$ & 73.65 & 26.35 & & 73.90 & 26.10 \\
$1979-81$ & 71.48 & 28.51 & & 72.39 & 27.61 \\
$1982-84$ & 67.94 & 32.06 & & 69.95 & 30.05 \\
$1985-87$ & 64.75 & 35.25 & & 69.19 & 30.81 \\
\hline
\end{tabular}

Sources: Shares by educational group are from Davis and Haltiwanger (1991). Shares by worker group are from ASM data from the NBER Productivity data set.

a. High school-educated workers include those who do not have a high school degree, as well as those with a high school degree. College-educated workers include those with some college but no degree, as well as those with a college degree. The percentage figures are for share of hours worked.

b. The percentage figures are for the share of employees in each group.

a sophisticated system of skill indexes linked to different industries and occupational categories. ${ }^{74}$ Their categories include cognitive skills, measured by a substantive complexity index and general educational development index; interactive skills, measured by an index; and motor skills, measured by an index..$^{75}$

We linked the Annual Survey of Manufactures data to the Howell and Wolff industry classifications and then regressed the ratio of production workers to total workers against the four Howell and Wolff skill indexes. If the ratio of production to total workers serves as a useful proxy for the overall skill level of an industry, we would expect the substantive complexity and general educational development indexes to be negatively correlated with this ratio and the motor skills index to be positively correlated with it. As for the interactive skills index, if one expects that more skill-intensive industries demand workers with more people and coordination skills, then this index should be negatively correlated with the ratio. If, however, one expects that relatively low-skill industries need a more supervisory-intensive approach to labor relations, then the index should be positively related to the ratio. ${ }^{76}$ Regression results are reported in table B3.

74. Howell and Wolff (1991a, 1991b, and 1992). Frederic Pryor has developed an analogous system of skill indexes that covers more skills than those discussed in the text.

75. These descriptions are from Howell and Wolff (1991b, p. 488).

76. See Howell and Wolff (1992, p. 136). 
Table B3. Regressions of the Howell and Wolff Measures for 1980 on 1980 Industry Ratio of Production Workers to Total Workers ${ }^{\mathrm{a}}$

\begin{tabular}{lcccc}
\hline \multirow{2}{*}{$\begin{array}{c}\text { Dependent } \\
\text { variable }\end{array}$} & Complexity & $\begin{array}{c}\text { General } \\
\text { education }\end{array}$ & Motor & Interactive \\
\cline { 2 - 5 } & $-4.32^{* *}$ & $-2.01^{* *}$ & 0.60 & $2.19^{* *}$ \\
Worker ratio & $(-7.57)$ & $(-7.35)$ & $(1.44)$ & $(7.42)$ \\
& $6.79^{* *}$ & $4.80^{* *}$ & $4.93^{* *}$ & $5.10^{* *}$ \\
Constant & $(16.32)$ & $(24.09)$ & $(16.22)$ & $(23.79)$ \\
Adjusted $\mathrm{R}^{2}$ & 0.62 & 0.60 & 0.03 & 0.61 \\
\hline
\end{tabular}

Source: Howell and Wolff (undated, 1991a, 1991b, and 1992). See text for details.

a. Results were similar when the skill measures for 1970 were regressed on the 1970 ratio of production workers to total employees. The number of observations is $36 . T$-statistics are in parentheses, and two aseterisks (**) indicate signficance at the 0.01 level.

Results show that the more skilled an industry, as measured by a lower ratio of production workers to total workers, the more likely it is to have high substantive complexity and general educational development requirements. The motor skills index does not appear to be closely correlated with the employment mix. And the less skilled an industry, the more likely it is to have high interactive skills requirements. This last association seems to lend support to Howell and Wolff's contention that more semiskilled operatives require more intensive supervision.

Clearly, not all nonproduction workers are skilled and not all production workers are unskilled. ${ }^{77}$ Despite anomalies, it appears that the rela-

77. Definitions from the 1990 Annual Survey of Manufactures (U.S. Bureau of the Census, 1992a) are as follows.

Nonproduction workers: "Those engaged in factory supervision above the line-supervisor level. It includes sales (including driver salespersons), sales delivery (highway truck drivers and their helpers), advertising, credit, collection, installation and servicing of own products, clerical and routine office function, executive, purchasing, financing, legal, personnel (including cafeteria, medical, etc.), professional, and technical employees. Also included are employees on the payroll of the manufacturing establishment engaged in the construction of major additions or alterations to the plant and utilized as a separate work force" (p. A-1).

Production workers: "Workers (up through the line-supervisor level) engaged in fabricating, processing, assembling, inspecting, receiving, sorting, handling, packing, warehousing, shipping (but not delivering), maintenance, repair, janitorial and guard services, product development, auxiliary production for plant's own use (power plant, etc.), recordkeeping, and other services closely associated with these production operations at the establishment covered by the report. Employees above the working-supervisor level are excluded from this item" (p. A-1). 
tive use of production and nonproduction workers is well related to the relative use of blue-collar and white-collar workers and to the relative use of less educated and more educated workers in a variety of instances. Likewise, in England, shares of manual and nonmanual employment in manufacturing are strongly correlated with educationbased shares, even though the manual category may include some highly skilled operatives, while the nonmanual category includes possibly lowskilled office employees. ${ }^{78}$ Given these relationships, on a first approximation, the production-nonproduction ratio serves well as a rough proxy for the general skill level of an industry. 


\title{
Comments and Discussion
}

\begin{abstract}
Alan Deardorff: I found the Sachs and Shatz paper very refreshing. I had occasion last year to read many of the papers they refer to-in the literature on the effects of trade on wages and employment-and I often found them difficult to follow. That was not the case here. The paper is very clearly done and also very informative. It reports on data that I have not seen before, and I was gratified to see that it was supportive, in terms of the trade patterns that were described, of the Heckscher-OhlinSamuelson trade model. In my comment, I will focus on the interpretation of their results, in particular whether they really answer the question that seems to lie behind this literature: whether recent changes in U.S. labor markets have been the result of external forces acting on the United States through international trade.
\end{abstract}

The issue, just to restate it, is that the 1980s saw an increase in U.S. trade, particularly imports, and an increase in the relative wage of skilled labor in the United States compared with unskilled labor. The question is whether these two events are related. Sachs and Shatz answer yes, though they claim for trade only a partial role in explaining what happened in labor markets. I think it quite possible they are correct, but I will argue that their formal analysis, like that of the labor economists who preceded them and who used essentially the same methodology, does not establish causation.

The heart of their substantive analysis is a calculation of what effects there would have been on demand for labor if the amount of trade had been held constant since 1978 relative to income. They calculate, based upon this hypothetical construction of trade, the factor content of the difference between actual and hypothetical trade. This is intended to show what the demand for labor in various sectors-and, therefore, for labor of various kinds-would have turned out to be. Thus the question 
they ask is what would have happened to U.S. labor markets if, starting in 1978, the United States had used quotas or some other form of trade restriction to limit the growth of trade to be no greater than the growth of final demand. Since trade did grow faster than income, the answer is that if we had done this, it would have been beneficial to unskilled labor. That is, had an increase in protection prevented trade from growing, the demand for unskilled labor would have increased relative to skilled labor. This is not surprising, though, and merely reflects a trade pattern consistent with the Heckscher-Ohlin Theorem and the presumption that the United States is relatively poorly endowed with unskilled labor.

Presumably, these effects on the quantities of labor demanded have implications for wages, although they are not developed in the paper. This is for good reason, since the connection between changes in labor demand and wages is more tenuous. Nonetheless, the notion is that this shift in labor demand away from unskilled labor toward skilled labor would have raised the relative wage of the latter, which is also consistent with Heckscher-Ohlin theory, in the form of the Stolper-Samuelson theorem. Neither is it surprising, in that the calculation implicitly finds the effects of an increase in protection.

Indeed, the same conclusions about the effects of "trade" on labor markets have been found by a number of labor economists who use a similar analytical technique. This paper uses a new and richer data set than they did, and it disaggregates trade with different trading partners to give a clearer picture of which trading relationships changed, and how. But aside from that and a greater completeness and clarity to the exposition, the paper does not add much to the work of the labor economists.

And also like the labor economists' contributions to this literature, this calculation does not really address the question of causality. One thing that has bothered me about this literature from the beginning is the tendency for people to ask whether trade has caused an effect on labor markets, as though, somehow, trade were exogenous. Indeed, Sachs and Shatz state explicitly that they view "the increased U.S. trade as an exogenous force affecting the United States and other economies, rather than as a result of U.S. macroeconomic policies or other U.S.-centered causes." Yet as a trade economist, I am much more inclined to explain trade on the basis of other things, rather than just take it as a forcing variable to affect other parts of the economy. 
There is a long list of reasons why those two observations-the increase in U.S. imports and the change in the relative wages of U.S. labor-could have occurred together. All of these are consistent with the Heckscher-Ohlin-Samuelson model but point to different exogenous changes, all of which would have had these two effects. Some originate outside the United States, others inside, and therefore one cannot use the coincidence of these two changes as evidence for one or the other. I will list just a few of the possibilities.

One is trade liberalization. The Tokyo Round of multilateral trade negotiations, for example, was completed at the end of the 1970s and went into effect during the 1980s. That presumably led to increased trade, and, based on the Stolper-Samuelson theorem, one would expect exactly these effects on relative wages.

Closely related to trade liberalization, and also working on the same Stolper-Samuelson linkage, would be various other things that could have happened abroad. The paper mentions foreign trade liberalization, something that Adrian Wood also emphasizes, I think appropriately. ${ }^{1}$ Simple growth of foreign economies abundant in unskilled labor would also have this effect. In both cases, increased participation in world markets by these countries would tend to lower the relative prices, on world markets, of non-skill-intensive goods, and again this would have the Stolper-Samuelson effects.

But there are also changes that could have occurred at home that would have had these same effects. The example that has been used by Lawrence and Slaughter, and by some others, is some form of technical progress inside the U.S. economy, although not just any form of technical progress will do. ${ }^{2}$ If technical progress occurs only in the skill-intensive sectors and if it is analyzed within the Heckscher-Ohlin-Samuelson framework, it would cause an increase in trade and a rise in the relative wage of skilled labor.

There are also other changes in the U.S. economy that could have had similar effects. One would be the mirror image of the sector-specific technical progress just mentioned: a decline in the technology, within the United States, in the non-skill-intensive sectors. Another would be an increase in overall spending relative to income, and the consequent

1. Wood (1994).

2. Lawrence and Slaughter (1993). 
worsening of the trade balance, which would increase demand for nontraded goods and require that more traded goods be sourced abroad. In this last example, if nontraded goods are skill intensive, then it will increase both imports and the skill differential.

The point is that many exogenous changes, some originating abroad and others at home, could have caused the observed changes in trade and wages. The analysis of factor content does not help to sort them out. Any or all of them could have contributed to the changes and the factor content analysis would be unaffected. Yes, it is no doubt true that if protection had been used to prevent trade from growing, U.S. unskilled workers would have benefited. But-to take two of the above examples-this is just as true if the increased trade were the result of domestic U.S. technical progress as if it were due to trade liberalization. In the latter case, one might reasonably have attributed the losses of the unskilled workers to trade. But in the former case, the losses are primarily due to technology, and the role of trade is only that trade policy could in principle have been used to prevent them.

Therefore, while the factor content analysis in the Sachs and Shatz paper does considerably improve the rendering of the labor economists' approach to this problem, it still fails to address the question of whether the ultimate source of these changes is to be found at home or abroad. However, the authors do address this issue at several points in the paper outside of their formal analysis, and they make some useful points.

They argue, for example, that because the increased trade with developing countries was concentrated with nine trading partners, it is unlikely that the increase could have been due to changes inside the United States. Although that argument is plausible, I can also imagine a shift within the developed world that would have provided precisely the market opportunities for a small group of developing countries whose comparative advantages and institutions were poised to take advantage of them.

They also argue that it is difficult to construct an explanation of observed trade and wages in terms of technological change that is also consistent with other data, including factor intensities and measurements of total factor productivity. That may be true, but their analysis of these issues is sketchy at best and seems meant as background.

The authors do deal more fully with a key question that had been raised by Bhagwati and by Lawrence and Slaughter, both of whom ob- 
served that the relative prices of non-skill-intensive goods on world markets had risen over the period, contrary to what would be needed for a Stolper-Samuelson explanation of the drop in unskilled wages. ${ }^{3}$ Sachs and Shatz find the Lawrence and Slaughter data unconvincing, and they provide their own analysis from a different source. As I understand it, Sachs and Shatz get the opposite conclusion about prices, but only after dummying out the computer sector, which appeared to be an outlier. I find this unconvincing, however, since it is precisely the computer sector that lies at the heart of some technological explanations of how the 1980s differed from preceding decades.

In the end, I can only wish that Sachs and Shatz had devoted less attention to repeating and improving the factor content analysis of their predecessors. In effect, it only shows that greater protection in the United States would have benefited unskilled labor. I would have preferred to see them take on more systematically the quantification of the exogenous changes that might have driven events in the 1980s. These would include both developing country growth and liberalization and developed country (or world) technological change. They might also include the capital flows they mention and the change in aggregate spending I mention. The results of such an analysis might well be the same as their original ones-that changes abroad have contributed to something like half of the changes in employment and wages that have been observed in the United States. But I would have more confidence in this conclusion if it had been addressed more directly.

Robert E. Hall: In this paper, the authors conclude that trade expansion has been one factor-probably not too large a factor-in the adverse experience of blue-collar workers in the United States since 1980. The conclusion is in line with common sense, given that the trading partners with the most growth in trade have a great many people ready to work with their hands and relatively few able to compete with the knowledge and coordination workers who populate the upper end of the U.S. wage distribution. The conclusion supports the consensus of a large literature in labor economics over the past few years. Although the authors see this paper as putting more emphasis on trade expansion as an

3. Bhagwati (1991) and Lawrence and Slaughter (1993). 
explanation of widening skill differentials in U.S. wages than do the writings of some prominent trade economists, including Jagdish Bhagwati, Paul Krugman, and Robert Lawrence, the difference is subtle. The authors agree with their colleagues that trade expansion is not the major factor in skill differentials, but they argue that expansion is more than a footnote.

A large literature on the sources of the widening of the wage distribution in the United States over the past 15 years has generally concluded that biased technical change is the principal factor. Apart from the possible influence of trade expansion, the other candidate would be an increase in the supply of unskilled workers. Little evidence supports the supply hypothesis; the trend toward a more highly educated labor force has continued just as strongly in the past 15 years as before. And the idea that the quality of education is a factor is pretty much refuted by the finding that older, less educated workers have been among the principal victims of change over the past 15 years. So the hypothesis that technical change has rendered the less skilled worker obsolete seems compelling, though it is hard to find direct evidence in its support.

The paper takes the position that "technical change that saves unskilled labor, if it comes in the form just described, would not be enough to account for the observed trends in wage inequality." However, the form of bias in technical change on which their proposition rests is sharply limited. Suppose, for example, that a new machine costing $\$ 4$ an hour to operate can do anything that an unskilled worker can do. Then the wage for unskilled work must fall to $\$ 4$ an hour. Although the real value of the earnings of the unskilled might not fall, certainly the earnings distribution would widen in this case. Both the strength and the weakness of the hypothesis of biased technical change is that it can explain any pattern of change in relative wages. Thus, the authors have little basis in theory for asserting that, besides technical change, "Something else is probably at work. One of Leamer's candidates, and ours, is international trade."

Table 11 of the paper ably demonstrates the United States' aggressive specialization in world markets during the period of rapid trade expansion. The demise of the apparel and footwear industry (in skill decile 10) and the expansion of the aircraft industry (in skill decile 2) are the paradigms of the paper.

Although specialization in skill-intensive tradables has continued re- 
morselessly, the effect within the entire U.S. labor market cannot have been large, as the calculations in table 13 show. Even within manufacturing, the effect of trade expansion since 1978 has been modest. And manufacturing is only about a sixth of the total U.S. economy. The widening of the wage distribution has occurred throughout the economy, so trade cannot be a major cause. If the manufacturing labor market were isolated from the rest of the economy, trade expansion effects would have been limited to the tradables sector (basically manufacturing), contrary to what is observed. Absent isolation, manufacturing is too small to have much effect on national wage patterns. The authors disappoint the reader by their unwillingness to venture a quantification of the effects of trade expansion on the wage distribution.

Sachs and Shatz disagree with empirical findings reported by Lawrence and Matthew Slaughter on relative prices. There should not be any real disagreement on this topic, because all sensible explanations of the structural changes influencing the U.S. economy over the past 15 years agree that less skill-intensive goods should have become cheaper relative to more skill-intensive ones. Plainly this follows from a view that the United States has opened its markets to goods made in low-wage countries with unskilled workers. Equally, if technology has found methods of production that have displaced low-skilled U.S. workers by methods that are even cheaper, relative prices should have moved in the same way. Thus, relative price changes are not a watershed issue. Lawrence and Slaughter's finding that skill-intensive goods have not become relatively more expensive is simply paradoxical, not supportive of any theory of structural change. The present paper takes another look at the data and concludes, unremarkably, that the prediction of all theories is upheld.

The authors mention, but do not pursue, the extra evidence that is available from the cross-country study of trade expansion. The evidence seems to support their views strongly. First, wage differentials have narrowed in previously low-wage countries, such as Korea, whose exports have risen substantially. Second, high-wage countries with managed trade-Japan and France-have had stable wage differentials. Third, aggressively free-market countries-the United States and Britainhave had widening differentials.

One topic important in the labor economics literature on recent changes in relative wages gets little attention here: the erosion of rents earned by blue-collar workers. The 15 -year period considered in this 
paper coincides with a remarkable decline in private sector unionism, particularly in industries most affected by trade expansion.

The paper documents the major role of transnational corporations in trade expansion. A conspicuous form of increasing specialization has occurred within corporations or between closely affiliated corporations. Product design, administration, and marketing occur in the United States, where workers who specialize in those activities are abundant, while actual production occurs in Mexico or Malaysia, where workers who specialize in working with their hands are plentiful and cheap. I found the summary data on this point compelling. I learned little more from the detailed gravity model. The finding is that TNC activity is associated with higher volumes of trade between a pair of countries than is predicted by a simple gravity model. All one learns from the estimation is that the MBAs working for the TNCs are better at spotting profitable opportunities for international specialization than is the gravity model.

With China just beginning to enter the world economy in a big way, and India showing signs of doing the same in the coming decade, the trend toward greater world specialization will continue rapidly into the future, the paper argues persuasively. Further atrophy of less skillintensive manufacturing is inevitable in the United States, and further opportunities will develop here for providing high-end inputs based on the superior problem-solving and creative skills of U.S. workers. As the authors conclude, maintaining the flexibility of the U.S. labor market in the face of these structural changes is essential.

\section{General Discussion}

Lawrence Katz emphasized that the authors' estimate of a 7 percent loss of manufacturing jobs resulting from trade is too small to explain much of the widening pay differential between skilled and unskilled workers. Given plausible elasticities of demand for unskilled workers, the loss of perhaps 5 percent of manufacturing jobs, which account for only about 17 percent of total employment in 1993, could have had real but modest impact on wage differentials. He argued further that even among high school dropouts, the least skilled group, job losses from increased trade in manufacturing are not big enough to explain the extent of the widening pay differential. Furthermore, Katz reported that the labor economics literature assigned at most a fifth of the increase in educa- 
tional wage differentials during the 1980s to extinguishing job rents from all causes, not just trade. And although expanding trade eliminated jobs in industries that paid rents to low-skilled workers, trade also provided a partial offset by shifting some less educated workers into higher-wage sectors. Gary Burtless pointed out that the timing is off for trade to be a major factor in explaining the widening pay gap. The big increase in trade occurred in the 1970s, but the pay differential has been widening since 1950, with a break during the 1960s when the differential showed no trend. He also added that although the wage differential between women and men has declined at every skill level, the skill differential among women has widened just as the skill differential among men has. Women at the bottom of the distribution actually have lower real wages than in 1973.

William Branson observed that in a country already fully open to trade, an increase in trade might affect employment in some industries but should not affect wages because factor prices would already be determined by world product prices. But Susan Collins observed that if an increase in trade is large enough to alter the mix of goods produced domestically, then wages can be affected too. Thus, trade may have important effects on relative wages in the future as large countries like China expand their role in the world economy.

Collins commended the paper's emphasis on the need to disaggregate when discussing trade effects. She noted that even if expanding trade has had a modest overall effect on U.S. labor markets, its effect has been significant for some industries and some regions. These differential effects help to explain the political difficulties that arise in defending free trade, because the benefits are widely distributed and the losses tend to be highly concentrated. The regional effects, in particular, warrant further study.

Martin Baily observed that technological change has to account for most of the rise in wage inequality, given broad trends in the data. And he suggested that technological change may underlie some of what is typically thought of as trade effects on employment. As an example, he cited the change in Toyota's production technology that sharply lowered costs. The resulting tougher foreign competition forced U.S. automakers to improve their own production technology, leading to job losses at U.S. firms. The employment effects are related to trade, but their root cause is the original technological change in Japan and its influence on U.S. technology. 
Baily also pointed out that technological change has not just affected manufacturing but also has reduced the relative demand for unskilled workers in service sectors, such as airlines, telecommunications, and banking. However, he raised the possibility that the skill differential might soon stop widening. In recent decades, technological change has had its largest negative impact on unskilled workers. But now, he noted, there are some signs, including layoff patterns in the past recession, that technological change may be helping firms economize on college graduates and middle managers.

George Perry emphasized that the difference between the authors' results on relative prices and total factor productivity and Lawrence and Slaughter's results appears sensitive to whether computers are in the sample of industries. Lawrence and Slaughter report that with computers included the relative prices of products from less skill-intensive industry rise and relative TFP growth in these industries is slower. Without computers, the effects are reversed. Sachs and Shatz omit computers on the grounds that their estimated price declines are both very rapid and measured with considerable uncertainty, yet they dominate the results. Lawrence and Slaughter argue that the computer industry should have some weight in the calculations, despite the measurement problems. Perry noted that it was difficult to choose the correct answer from these conflicting procedures and results.

Several panel members emphasized the importance of labor market institutions and features of the labor supply in understanding differences in employment and wage distributions across countries. Baily argued that France would have experienced the same relative wage trends as Britain and the United States, except for its rigid wage-setting institutions. Katz noted that Mexico's recent trade liberalization would have reduced wage differentials if the forces toward factor price equalization were all that were at work. Inequality, however, has been growing because of other changes in the labor market, including a decline in the minimum wage and a reduction of "rents" earned by low-skilled workers as industries were privatized. He also noted that, in Korea, a rapidly increasing supply of more educated workers helps explain the fall in the skill differential. 


\section{References}

Abowd, John M. 1991. "Appendix: The NBER Immigration, Trade, and Labor Markets Data Files." In Immigration, Trade, and the Labor Market, edited by John M. Abowd and Richard B. Freeman. Chicago: University of Chicago Press.

Abraham, Katharine G., and Susan N. Houseman. 1993. "Earnings Inequality in Germany." Working Paper 4541. Cambridge, Mass.: National Bureau of Economic Research (November).

Andrews, Stephen, and Craig Zabala. 1984. Technical Notes: Documentation of the SRI-Penn Manufacturing Industry Dataset Developed by David L. Crawford, Gary Fromm, Lawrence R. Klein and Frank C. Ripley. Washington: U.S. Bureau of the Census.

Bach, Christopher L. 1980. "U.S. International Transactions, Fourth Quarter and Year 1979." Survey of Current Business 60(3): 44-72.

1992. "U.S. International Transactions, Fourth Quarter and Year 1991." Survey of Current Business 72(3): 51-93.

Bednarzik, Robert W. 1993. "An Analysis of U.S. Industries Sensitive to Foreign Trade." Monthly Labor Review 116(2): 15-31.

Berman, Eli, John Bound, and Zvi Griliches. 1994. "Changes in the Demand for Skilled Labor Within U.S. Manufacturing Industries: Evidence from the Annual Survey of Manufacturing." Quarterly Journal of Economics 109(2): 36797.

Bernard, Andrew B., and J. Bradford Jensen. 1993. "U.S. Manufacturing Exports, Jobs, and Wages." Unpublished paper. Massachusetts Institute of Techonology (December).

Bhagwati, Jagdish. 1991. "Free Traders and Free Immigrationists: Strangers or Friends?" Working Paper No. 20. New York: Russell Sage Foundation.

- and Vivek Dehejia. 1993. "Freer Trade and Wages of the Unskilled: Is Marx Striking Again?" Paper prepared for the Conference on the Influence of Trade on U.S. Wages, American Enterprise Institute (September 10).

Blau, Francine D., and Lawrence M. Kahn. 1994. "International Differences in Male Wage Inequality: Institutions Versus Market Forces." Working Paper 4678. Cambridge, Mass.: National Bureau of Economic Research (March).

Borjas, George J., and Valerie A. Ramey. 1993. "Foreign Competition, Market Power, and Wage Inequality: Theory and Evidence." Working Paper 4556. Cambridge, Mass.: National Bureau of Economic Research (December).

Borjas, George J., Richard B. Freeman, and Lawrence F. Katz. 1991. "On the Labor Market Effects of Immigration and Trade." Working Paper 3761. Cambridge, Mass.: National Bureau of Economic Research (June).

Davis, Steven J. 1992. "Cross-Country Patterns of Change in Relative Wages." Working Paper 4085. Cambridge, Mass.: National Bureau of Economic Research (June).

— 
U.S. Manufacturing Plants, 1963-1986." Working Paper 3722. Cambridge, Mass.: National Bureau of Economic Research (May).

Deardorff, Alan V. 1994. "An Overview of the Stolper-Samuelson Theorem." In The Stolper-Samuelson Theorem: A Golden Jubilee, edited by Alan V. Deardorff and Robert M. Stern. Ann Arbor: University of Michigan Press (forthcoming).

— of Trade." Journal of International Economics 24(1/2): 93-107.

The Economist. 1990. The Economist Book of Vital Statistics. London: Random House.

Feldstein, Martin. 1994. "The Effects of Outbound Foreign Direct Investment on the Domestic Capital Stock." Working Paper 4668. Cambridge, Mass.: National Bureau of Economic Research (March).

Fitzpatrick, Gary L., and Marilyn J. Modlin. 1986. Direct Line Distances, United States Edition. Metuchen, N.J.: Scarecrow Press.

Freeman, Richard B. 1993. "Is Globalisation Impoverishing Low Skill American Workers." Unpublished paper. Urban Institute (November).

General Agreement on Tariffs and Trade. 1993. International Trade 1993: Statistics. Geneva: GATT.

Gray, Wayne B. 1987. "The Cost of Regulation: OSHA, EPA and the Productivity Slowdown." American Economic Review 77(5): 998-1006.

1989. "Productivity Database." Unpublished paper. National Bureau of Economic Research (June).

— 1992. "Updating Productivity Data Through 1989." Unpublished paper. National Bureau of Economic Research (April).

Grubel, Herbert G., and P. J. Lloyd. 1975. Intra-Industry Trade: The Theory and Measurement of International Trade in Differentiated Products. New York: John Wiley and Sons.

Hickok, Susan. 1993. "Recent Trade Liberalization in Developing Countries: The Effects on Global Trade and Output." Federal Reserve Bank of New York Quarterly Review 18(3): 6-19.

Howell, David R., and Edward N. Wolff. 1991a. "Skills, Bargaining Power and Rising Interindustry Wage Inequality since 1970." Review of Radical Political Economics 23(1-2): 30-37.

- 1991b. "Trends in the Growth and Distribution of Skills in the U.S. Workplace, 1960-1985." Industrial and Labor Relations Review 44(3): 486502 .

1991c. "Trends in the Growth and Distribution of Skills in the U.S. Workplace, 1960-1985: Data Appendix." Unpublished paper. New School for Social Research.

1992. "Technical Change and the Demand for Skills by U.S. Industries." Cambridge Journal of Economics 16(2): 127-46.

Hufbauer, Gary Clyde, Diane T. Berliner, and Kimberly Ann Elliott. 1986. Trade Protection in the United States: 31 Case Studies. Washington: Institute for International Economics. 
International Labour Office. 1966. Year Book of Labour Statistics 1965. Geneva: ILO.

1978. Year Book of Labour Statistics 1978. Geneva: ILO.

- 1983. Year Book of Labour Statistics 1983. Geneva: ILO.

- 1993. Year Book of Labour Statistics 1993. Geneva: ILO.

Katz, Lawrence F., Gary W. Loveman, and D. G. Blanchflower. 1993. "A Comparison of Changes in the Structure of Wages in Four OECD Countries." Working Paper 4297. Cambridge, Mass.: National Bureau of Economic Research (March).

Kim, Dae I., and Robert Topel. 1994. "Labor Markets and Economic Growth: Lessons from Korea's Industrialization, 1970-90." In Differences and Changes in Wage Structure, edited by Richard B. Freeman and Lawrence Katz. Chicago: University of Chicago Press (forthcoming).

Landesmann, Michael, and Pascal Petit. 1992. "Trade in Producer Services: International Specialisation and European Integration.” Working Paper 9217. Cambridge: Department of Applied Economics, University of Cambridge (November).

Lardy, Nicholas R. 1994. China in the World Economy. Washington: Institute for International Economics.

Lawrence, Robert Z., and Matthew J. Slaughter. 1993. "Trade and U.S. Wages: Giant Sucking Sound or Small Hiccup?” BPEA, Microeconomics, 2:1993, 161-210.

Leamer, Edward E. 1993. "Wage Effects of a U.S.-Mexican Free Trade Agreement." In The Mexico-U.S. Free Trade Agreement, edited by Peter M. Garber. Cambridge, Mass.: MIT Press.

- 1994. "Trade, Wages and Revolving Door Ideas." Working Paper 4716. Cambridge, Mass.: National Bureau of Economic Research (April).

Levy, Frank, and Richard J. Murnane. 1992. "U.S. Earnings Levels and Earnings Inequality: A Review of Recent Trends and Proposed Explanations." Journal of Economic Literature 30(3): 1333-81.

Machin, Stephen. 1994. "Changes in the Relative Demand for Skills in the U.K. Labour Market." In The Skills Gap and Economic Activity, edited by Alison Booth and Dennis Snower. Cambridge: Cambridge University Press.

MacPherson, David A., and James B. Stewart. 1990. "The Effect of International Competition on Union and Nonunion Wages." Industrial and Labor Relations Review 43(4): 435-46.

McGrath, Michael E., and Richard W. Hoole. 1992. "Manufacturing's New Economies of Scale." Harvard Business Review 70: 94-102.

Murphy, Kevin M., and Finis Welch. 1991. "The Role of International Trade in Wage Differentials." In Workers and Their Wages: Changing Patterns in the United States, edited by Marvin H. Kosters. Washington: AEI Press. 107(1): 285-326.

Revenga, Ana L. 1992. "Exporting Jobs? The Impact of Import Competition on 
Employment and Wages in U.S. Manufacturing." Quarterly Journal of Economics 107(1): 255-84.

State Statistical Bureau of the People's Republic of China. 1992. China Statistical Yearbook. Beijing: China Statistical Information and Consultancy Service Center.

Stolper, Wolfgang F., and Paul A. Samuelson. 1941. "Protection and Real Wages." Review of Economic Studies 9: 58-73.

Summers, Robert, and Alan Heston. 1991. "The Penn World Table (Mark 5): An Expanded Set of International Comparisons 1950-1988." Quarterly Journal of Economics 106(2): 327-68.

United Nations. 1961. Commodity Trade Statistics. Vol. 10, no. 4, part 7. New York: United Nations.

- 1992. World Investment Report. New York: United Nations.

- 1993. World Investment Report. New York: United Nations.

U.S. Bureau of the Census. 1962. Annual Survey of Manufactures 1959 and 1960. Washington: Department of Commerce.

- 1971. 1970 Census of Population Alphabetical Index of Industries and Occupations. Washington: Department of Commerce.

- 1976. 1972 Census of Manufactures. Washington: Department of Commerce.

- 1978. Foreign Trade Statistics Data Finder. Washington: Department of Commerce.

- 1981. 1979 Annual Survey of Manufactures: Statistics for Industry Groups and Industries. Washington: Department of Commerce.

- 1992a. 1990 Annual Survey of Manufactures: Statistics for Industry Groups and Industries. Washington: Department of Commerce.

- 1992b. 1991 Annual Survey of Manufactures: Statistics for Industry Groups and Industries. Washington: Department of Commerce.

- Various years. U.S. Commodity Exports and Imports as Related to Output. Washington: Department of Commerce.

U.S. Bureau of Economic Analysis. 1981. U.S. Direct Investment Abroad, 1977. Washington: Department of Commerce.

- 1991a. U.S. Direct Investment Abroad: Operations of U.S. Parent Companies and their Foreign Affiliates, Revised 1990 Estimates. Washington: Department of Commerce.

- 1991b. The 1982 Benchmark Input-Output Accounts of the United States. Washington: Department of Commerce.

U.S. Federal Trade Commission. 1985. Annual Line of Business Report 1977: Statistical Report of the Bureau of Economics to the Federal Trade Commission. Washington: Federal Trade Commission.

U.S. International Trade Commission. 1993. The Economic Effects of Significant U.S. Import Restraints. Washington: International Trade Commission.

U.S. Office of Federal Statistical Policy and Standards. 1978. Standard Indus- 
trial Classification Manual: 1977 Supplement. Washington: U.S. Department of Commerce.

U.S. Office of Management and Budget. 1972. Standard Industrial Classification Manual. Washington: Office of Management and Budget.

-1987. Standard Industrial Classification Manual. Washington: Office of Management and Budget.

Wood, Adrian. 1994. North-South Trade, Employment and Inequality: Changing Fortunes in a Skill-Driven World. Oxford: Clarendon Press.

World Bank. 1979. World Development Report. New York: Oxford University Press.

1993. World Development Report. New York: Oxford University Press. 